\title{
Economic Globalization and Population Health Outcomes in Nigeria: Implications of Achieving the Health Sustainable Development Goals (SDGs).
}

\author{
Nicholas Attamah, Ph.D. ", Chris U. Kalu, Ph.D ${ }^{* *}$ \\ * Department of Economics, Enugu State University of Science and Technology, Enugu \\ ${ }^{* *}$ Department of Economics, Nnamdi Azikiwe University, Awka. \\ DOI: 10.29322/IJSRP.10.10.2020.p10671 \\ http://dx.doi.org/10.29322/IJSRP.10.10.2020.p10671
}

\begin{abstract}
Globalization as a whole, and economic globalization in particular is a key challenge to public health outcomes, especially in developing countries. The paper examined the effects of economic globalization on health outcomes in Nigeria. Specifically, it showed the drivers of health outcomes in Nigeria. The paper covered the period of 1970-2020 and the vector error correction model (VECM) approach was utilized on data sourced from Central Bank of Nigeria Statistical Bulletin of various years and the World Bank Development Indicator (WDI, 2019) database. The result showed that health infrastructure, foreign aid, population growth, access to sanitation were significantly and negatively related to health outcomes while real gross domestic product(GDP) and index of globalization were positively and significantly related to health outcome, such that $1 \%$ increase in health infrastructure brought about $17 \%$ decrease in infant mortality rate and $1 \%$ increase in foreign aid brought about $7 \%$ decrease in infant mortality rate. It further showed that $1 \%$ increase in population growth rate brought about $4.64 \%$ decrease in infant mortality rate and $1 \%$ increase in access to sanitation brought about $1.12 \%$ decrease in infant mortality rate. The implications of these results on the relationship between economic globalization and health outcomes were discussed. The paper concludes that globalization may not have address health outcomes in Nigeria via extant factors including micro and macro issues. Therefore, a genuinely health-centered process of globalization can be achieved only by ensuring that the interest of developing countries, Nigeria inclusive and vulnerable populations are fully represented in global decision-making processes.
\end{abstract}

Index Terms- Economic globalization, infant mortality rate, under-five mortality, sustainable development goal, vector error correction (VECM), Nigeria.

JEL Codes: F6, QO1, Q53, I12, G11

\section{INTRODUCTION}

$\mathrm{T}$ There are various explanations to health outcomes. However, the World Health Organization (WHO) defines population health outcomes as changes in the health of an individual, group of people, or the population that is attributable to an intervention or series of interventions. Accordingly, measures of outcome or health status include: mortality, re-admission, patient experience, effectiveness of care, timeliness of care, efficient use of medical imaging, and so on (Krabbe, 2016). Meanwhile Anyanwu (2007) has submitted that infant mortality rate (IMR) and the under-five mortality rate (U5-MR) are the most widely used measures in the health literature of health outcomes. The U5-MR is the probability of dying between birth and age five years expressed per 1000 live births, which have been used as a measure of children's well-being. The infant mortality rate is the number of deaths per 1000 live births of children under one year of age. It is regarded as a sensitive measure of the availability, utilization and effectiveness of healthcare system, used for comparing health system, programmes and policies internationally (Health Policy Institute, Ohio, 2007). In the paper, we used infant mortality rate measures to capture population health outcomes. In Nigeria, infant and child mortality has remained seemingly high. Using the trend and profile, in 2015, about 9\% deaths of newborn babies in the world occurred in Nigeria, thus placing Nigeria as the third country in the world with the highest infant mortality rate outside India and Pakistan (Owoseye, 2017; Joseph, 2018), as Nigeria recorded $69.4 \%$ death rate per 1,000 infants. The lack of access to basic health facilities and resources due to environmental and social barriers (such as the isolation of those in rural areas, the absence of health facilities in rural areas and poverty) contributes immensely to the increase in infant mortality in Nigeria. Nigeria is among the nations in sub-Saharan Africa with very high under-five mortality rates (UNICEF, 2014; Anthony, Isaac and Victor, 2019). The U-5 mortality rate in the 1990s for example was 201 deaths per 1000, which later dropped to 128 deaths per 1000 within the 2000 s and has continued to drop in the recent time. Again, according to the 2017 National Development Health Survey (NDHS), the most recent data available, infant and child mortality is 69 and 64 per 1000 live births respectively. This implies that one in every 15 Nigerian child dies before reaching age 1 , and one in every sixteen does not live to their fifth birthday from birth.

There are various components of globalization. However, the Peterson Institute for International Economics (PIIE, 2018) 
defined globalization as the growing independence of the global economies, cultures, and populations, brought about by crossborder trade in goods and services, technology, and flows of investment, people and information. The focus of this paper is on the economic dimensions of globalization. In the words of Anyanwu (2006) and Farzanegan and Hazzan (2017), economic globalization has two dimensions: international trade dimension, proxy by trade openness or liberalization and capital flow dimension, proxy by foreign direct investment (FDI) and foreign portfolio investment (FPI).

There are multiple and indirect linkages between globalization and health outcomes. The direct linkages include impact of globalization on health system and policies operating directly on health (e.g. the effects of World Trade Organization (WTO) General Agreement on Trade in Services (GATs) and through international markets (e.g. The effect on pharmaceutical prices of the WTO Agreement on Trade-Related Aspects of Intellectual Property Rights (TRIPs); and the direct effects on other influences on health at the population levels (e.g. crossborder transmission of infectious disease and marketing of tobacco). The indirect effects includes effects operating through the national economy on the health sector (e.g. effects of trade liberalization and financial flows on the availability of resources for public expenditure on health, and on the cost of inputs); and on population risks (particularly the effects on nutrition and living conditions resulting from impacts on household income) (Woodward, Drager, Beaglehole \& Lipson, 2001).

The research questions arising from the background information is as follows: How does economic globalization affect infant mortality in Nigeria? What are the transmission mechanisms through which economic globalization affects infant mortality rates in Nigeria? The objective(s) of the paper are framed thereof. The theoretical, empirical and methodological justification of the paper is not in doubt. While plethora of studies (see Temikin \& Veizaga, 2010; Farganegan et al, 2017; Verter, 2014; Mohanty, 2017; Wako, 2018; Ali et al., 2018; Song et al., 2017. Goldberg, 2007; Westling, 2012; have conducted studies on economic globalization and unemployment; tourism; environment; inequality; economic growth; labour market; higher education; migration; corporate structure and income distribution, there is yet to be identified study on economic globalization and health status or outcome at specific country level. The study by Novignon and Atakorah (2016) focused on trade openness (an integral part of globalization, which is not globalization) and the health sector including health financing which is not a health outcome at the sub-Saharan African level with its unobserved heterogeneity. The study of Popoola (2018) focused on economic globalization and life expectancy (and life expectancy is also based on the mortality rate, although more comprehensive measures would include indicators measuring mortality rate) (Wang,2002). The paper contributes and extends the literature on economic globalization (trade openness and foreign direct investment) and health outcome (infant mortality and under-five mortality) in four ways: First, the paper is country specific, using Nigerian dataset to show some interesting stylized facts on the subject matter. Second; the paper empirically investigates the effect of economic globalization (using the KOF index of trade openness and FDI inflow) on health outcomes (infant mortality, recognized in the literature as a measure of health status/outcome) in Nigeria with a view of drawing some key policy lessons. Third, the paper incorporates other key drivers of health outcomes not considered by the study of Popoola (2018) which include; real gross domestic product (RGDP); health infrastructure (HELINFR); overseas development assistance (ODA); population rate (POPR); access to sanitation (SANITA). Four, we offer policy suggestions in the light of the empirical evidence that would help the Nigerian policymakers to manage economic globalization in such a way as to limit the negative effects on health outcome and increase opportunities for its improvement. Fifth, we used the conventional KOF index of economic globalization and the vector autoregression (VAR) with its impulse response function (IRF) and variance decomposition (VDC) to investigate the magnitude of shocks of economic globalization on health outcomes as well as the transmission mechanism.

The paper is divided as follows: section II discusses some stylized facts on health outcomes in Nigeria within the reviewing period (1970-2018); section III presents the literature review while section IV examines the model, data and methods. Section $\mathrm{V}$ discusses the empirical results of the estimation process and section VI concludes the paper with policy implications, focusing on what can be done within the policy arena to achieve Goal 3"Good health and well-being of the Sustainable Development Goal (SDGs) in Nigeria.

\section{SOME STYLIZED FACTS ON ECONOMIC GLOBALIZATION AND HEALTH OUTCOMES IN NIGERIA}

Although, the global number of child deaths remains high, the world has made tremendous achievements in reducing child and young adolescent mortality over the past few decades. The global under-five mortality rate declined by 59 percent from 93 deaths per 1,000 live births in 1990 to 39 in 2018, while mortality rate among children ages 5-14 years fell by 53 percent from 15 to 17 deaths per 1,000 children age 5 in 2018. Still, the number of children aged 0-14 years died in 2018 (Child Mortality Report, 2019). Meanwhile, out of the 195 countries analyzed in the Child Mortality Report, 121 countries already met the SDG targets on under-five mortality, and 21 countries are expected to do so by 2030 if sustained efforts are maintained. However, efforts to accelerate progress need to be scaled up in the remaining 53 countries, two thirds of which are in subSaharan Africa, if the SSA countries are to achieve the SDG target on under-five mortality. Based on the global relationship of neonatal mortality to under-five mortality, observed for all the countries in the report, sub-Saharan Africa had the highest neonatal mortality rate in 2018 at 28 deaths per 1,000 live births, followed by Central and Southern Asia with 25 deaths per 1,000 live births. By implication, a child born in sub-Saharan Africa is 10 times more likely to die in the first month than a child born in a high-income country like the USA.

From the Multiple Indicator Cluster Survey (2016-2017) on Children and Women conducted by National Bureau of Statistics and United Nations Children's Fund (UNICEF), neonatal mortality rate is estimated at 39 per 1,000 live births, while postneonatal mortality rate is at 31 per 1,000 live births in Nigeria. Infant mortality rate, often used as indicator of health status of a country, on the other hand is 70 per 1,000 live births, while 
under-five mortality rate is 120 per 1000 live births. This implies that in five years preceding the survey, 1 in 15 live births in Nigeria die before their first birthday, while 1 in 9 live birth die before their fifth birthday. About 1 in 19 children surviving to age 12 months die before celebrating their fifth birthday. From the survey, Nigeria requires a 69 percent reduction from her current mortality rate to achieve the SDG 3.2 target of 25 per 1,000 live births within a period of 13 years. Also, she requires 79 percent reduction in current under five mortality rates to meet the SDG target.

Table 1: Early Childhood Mortality Rates in Nigeria (20162017)

\begin{tabular}{|c|c|c|c|c|c|c|}
\hline \multicolumn{7}{|c|}{$\begin{array}{l}\text { Neonatal, post-neonatal, infant, child and under-five } \\
\text { mortality rates for five-year periods preceding the survey, } \\
\text { Nigeria; 2016-2017 }\end{array}$} \\
\hline $\begin{array}{l}\text { Years } \\
\text { precedi } \\
\text { ng the } \\
\text { survey }\end{array}$ & $\begin{array}{l}\text { Peri } \\
\text { od }\end{array}$ & $\begin{array}{l}\text { Neonat } \\
\text { al } \\
\text { mortali } \\
\text { ty } \\
\text { Rate- }^{1}\end{array}$ & $\begin{array}{l}\text { Post- } \\
\text { neonat } \\
\text { al } \\
\text { mortali } \\
\text { ty } \\
\text { rate_-,a }\end{array}$ & $\begin{array}{l}\text { Infant } \\
\text { mortali } \\
\text { ty rate }^{3}\end{array}$ & $\begin{array}{l}\text { Child } \\
\text { mortali } \\
\text { ty rate }^{4}\end{array}$ & $\begin{array}{l}\text { Under- } \\
\text { five } \\
\text { mortali } \\
\text { ty rate }^{5}\end{array}$ \\
\hline $0-4$ & $\begin{array}{l}2013 \\
- \\
2017\end{array}$ & 39 & 31 & 70 & 54 & 120 \\
\hline $\begin{array}{r}5 \\
\text { a Post } \\
\text { betwee }\end{array}$ & $\begin{array}{l}\text { MICS } \\
\text { indicato } \\
\text { MICS } \\
\text { rate }{ }^{4} \mathrm{M} \\
\text { MICS i } \\
\text { mortalit } \\
\text { eonatal } \\
\text { the infa }\end{array}$ & $\begin{array}{l}\text { ndicator } \\
\text { r 1.3- Pos } \\
\text { dicator } 1 \\
\text { CS indica } \\
\text { ndicator } \\
\text { y rates } \\
\text { nortality } \\
\text { t and neo }\end{array}$ & $\begin{array}{l}1.1 \text {; Neol } \\
\text {-neonatal } \\
2 ; \text { SDG i } \\
\text { tor 1.4-Ch } \\
.5 ; \mathrm{MDG}\end{array}$ & $\begin{array}{l}\text { atal mol } \\
\text { mortality } \\
\text { adicator? } \\
\text { ild morta } \\
\text { indicato }\end{array}$ & $\begin{array}{l}\text { ality rate } \\
\text { rate } \\
\text { 2-Infant } n \\
\text { ity rate } \\
4.1-\text { un }\end{array}$ & $\begin{array}{l}{ }^{\text {MICS }} \\
\text { nortality } \\
\text { der five } \\
\text { rence }\end{array}$ \\
\hline
\end{tabular}

Sources: National Bureau of Statistics (NBS) and United Nations Children's Fund (UNICEF) Multiple Indicator Cluster Survey (2016-2017).

On the socioeconomic characteristics of the early childhood mortality rates computed for the geographical zones, states, residence and maternal education, the survey reported that mortality rates were lower in the southern part of the country than the northern part. All the mortality rates are consistently highest in the north western region, while neonatal, infant and under-five mortality rates are lowest in the South-South region for the five years preceding the survey. Post-neonatal and child mortality rates are however lowest in the South West of Nigeria. The chances of the child surviving to first birthday are 2.2 times higher in the South-South than in the North West while for under-five, it is 2.7 times higher. Urban-rural mortality differential is also pronounced across early childhood age groups. As expected, mortality rates in urban areas are lower than rural areas in Nigeria. Infant mortality rate is 77 per 1,000 live births in the rural areas, while it is 53 per, 1000 live births in urban areas. Also, children survival to fifth birthday is 1.8 times higher in urban than rural areas.

Maternal education is expected to have inverse relationship with early childhood mortality. The survey also showed that neonatal, post-neonatal, infant, child and under-five mortality rates decreases with higher level of maternal education in Nigeria. This is more evident on child mortality rate, where women with non-formal education have a rate of 86 per 1,000 livebirths, while those with higher education have 9 per 1,000 livebirths. Early childhood mortality rates decrease as household wealth index increases. Infant mortality among the poorest household is higher ( 80 per 1,000 livebirths) than the richest (45 per 1000 livebirths). One in 6 children under-five who lives in the poorest household in Nigeria will likely die before their fifth birthday, compared to 1 in 18 in the richest quintile households. While the national average of under-five mortality rate is relatively high and still far from the target of Sustainable Development Goal in Nigeria, 9 states have higher values than the national average, including; Nasarawa, Niger, Bauchi, Gombe, Jigawa, Kano, Katsina, Kebbi and Zamfara. Box 1 presents an overview of health outcomes in Nigeria following the MICS of 2016-2017

Box 1: Key finding of the Multiple Indicator Cluster Survey, 2016-2017.

$>$ Neonatal mortality is 39 per 1,000 livebirths

$>$ Infant mortality rate is 70 per 1,000 livebirths

$>$ Under-five mortality rate is 120 per 1,000 livebirths

$>$ One in 15 livebirths in Nigeria die before their first birthday

$>$ One in 9 lives births die before their fifth birthday

$>$ One in 6 children who lives in the poorest household in Nigeria die before their fifth birthday

$>$ Nine states have higher under-five mortality rates than the national averages: Nasarawa, Niger, Bauchi, Gombe, Jigawa, Kano, Katsina, Kebbi and Zamfara

$>$ To achieve SDG. 3.2, there must be at least $5 \%$ reduction in early childhood mortality rates before 2030 across all groups.

Source: NBS \& UNICEF, 2018:38

Analysis by the Oxford Business Group (OBG) suggests that the development of the Nigerian healthcare system has been hindered by several notable challenges, including limited public funding, a high communicable diseases burden, rising incidence of non-communicable diseases, elevated rates of infant and maternal mortality rates (Medic West Africa, 2019). Similarly, the World Health Organization (WHO) over the years have highlighted that there is high incidence/reliance on out-of-pocket (OOP) health payments as a means of financing health system in Nigeria and that this has continued for many years in spite of a consensus to move closer to universal health coverage (UHC) and sustain it when achieved. The Economic Recovery and Growth Plan 2017-2020(ERGP), a plan document of the present Government summarizes several reasons for the poor performance of the country's healthcare services. Accordingly, these include insufficient financing, inadequate and inequitable access, weak supply chain management, limited human resource capacities and insufficient coordination, cohesion and accountability. The Federal Government's health policy under the ERGP 2017-2020 aims to improve the availability, accessibility, affordability and quality of health services by increasing access to primary healthcare services, expanding health coverage and improving the quality of the services provided. The policy initiatives to achieve these goals are: 
revitalizing the primary healthcare system, the rollout of UHC, strengthening delivery beyond the primary healthcare system, partnering with the private sector to develop mega-health services, and optimizing the health-to-population ratio in the country.

The World Trade Organization (WTO) has underlined the role of foreign direct investment (FDI) in the efficient utilization of scare resources and growth acceleration in poor countries such as the SSA economies. However, given the bad reputation that has befallen the African continent in general due to corruption, political instability and others causes in recent times, it has become difficult for the sub-region to attract substantial FDI compared to her peers such as the Latin-Americans, Middle East and Asia. Available Statistics from UNCTAD in 2018 reveals that international trade for developing economies declined from 31 percent in 2006 to 22 percent in 2017. FDI to West Africa fell 15 percent to $\$ 9.6$ billion, the lowest level since 2006 . This was largely due to the substantial drop in FDI flow to Nigeria, for the second consecutive year. Foreign investors may have adopted a cautious approach and withhold planned investment in light of the risk of instability associated with Nigeria's 2019 preelections period and disputes between the Government and some large MNEs. In 2018, both HSBC (United Kingdom) and UBS (Switzerland) closed their local representative offices in Nigeria, and the telecommunication giants MTN (South Africa) remained in litigation related to the repatriation of profits. In addition, international oil companies have been ordered to pay $\$ 20$ billion in back taxes. Nevertheless, investment by oil companies, which included significant reinvested earnings by established investors, remained prominent in 2018. The new policy to reduce public ownership in joint-venture assets to 40 percent could drive up FDI in Nigeria in the coming years (UNCTAD, 2019).

Nigeria's total trade in goods in 2017 was $\$ 92.2 \mathrm{bn}$ (\$51.5bn exports, \$40.7bn imports) comprising of \$75.8bn from formal trade $(\$ 44.5 \mathrm{bn})$ exports and $\$ 31.3 \mathrm{bn}$ imports) and $\$ 16.4 \mathrm{bn}$ from informal trade (\$7bn exports, \$9.4bn imports). Informal trade involved unrecorded cross-border transactions in agricultural products, livestock, and parallel trade including trans-shipment and smuggling Nigeria's trades within Africa in 2017 of \$6bn (\$4.9bn exports, \$1.1bn imports), represented 8\% of its total trade in goods, making her the $4^{\text {th }}$ highest intraAfrican trader in goods after South Africa (\$31.8bn), Nambia (\$6.8bn) and Zambia (\$6.7bn) (Guobadia, 2019).

Crude oil and gas accounted for 95\% of Nigeria's formal exports to the world in 2017, while agricultural commodities and manufactured products accounted for $2.5 \%$ and $2 \%$ respectively. While the main importers of Nigeria's goods in Africa are: South Africa, Togo, Cote d' Ivoire, Senegal, and Cameron, the major African exporters to Nigeria are South Africa, Morocco, Cote d' Ivoire, Swaziland and Egypt. Meanwhile, Nigeria's global trade in services of $\$ 23.25 \mathrm{bn}$ in 2015 made her the $3^{\text {rd }}$ highest African country in trade in services, after Egypt (\$36.06bn) and South Africa $(\$ 30.58 \mathrm{bn})$. Although Nigeria maintained the same value in its trade in services in 2017 (\$23.26bn), Nigeria was pushed down to the $4^{\text {th }}$ position by Morocco, which grew her services in trade from $\$ 22.6 \mathrm{bn}$ in 2015 to $\$ 27.06 \mathrm{bn}$ in 2017. In addition, Nigeria has been experiencing an unfavorable balance of trade in services vis-à-vis other African countries. In 2017, Nigeria's imports of services, at $\$ 18.2 \mathrm{bn}$, far outweighed exports, at $\$ 5 \mathrm{bn}$, resulting in a huge balance of trade deficit of $\$ 13.2 \mathrm{bn}$. On the other hand, Egypt and Morocco achieved trade surpluses. Nigeria's trade in services is dominated by transport, travel and other business services, which together accounted for $86 \%$ of services import and $76 \%$ of export. In 2017, travel services, which include citizen's expenditure for business and personal travel on short term trips abroad (less than 1 year) for education, health, leisure and so on, amounted to $\$ 8.33 \mathrm{bn}$ or $36 \%$ of Nigeria's total trade in services (Guobadia, 2019). In July 7, 2019, Nigeria signed into the African Continental Free Trade Area (AFCFTA) with the benefits thereof. Table 2.1 presents an overview of Africa's trade pattern as at 2017 amongst the African zones or blocs.

Table 2: Africa's Trade Pattern as at 2017

\begin{tabular}{|c|c|c|c|c|c|c|c|c|c|}
\hline $\begin{array}{l}\text { RE } \\
\text { C } \\
\text { Nam } \\
\text { e }\end{array}$ & $\begin{array}{l}\text { GD } \\
\mathbf{P} \\
\text { (\$B } \\
\text { n) }\end{array}$ & $\begin{array}{l}\text { \% } \\
\text { of } \\
\text { Af } \\
\text { ric } \\
\text { a } \\
\text { G } \\
\text { DP }\end{array}$ & $\begin{array}{l}\text { Popu } \\
\text { latio } \\
\text { n } \\
\text { (Mil) }\end{array}$ & $\begin{array}{l}\text { \% } \\
\text { of } \\
\text { Af } \\
\text { ric } \\
\text { a } \\
\text { Po } \\
\text { pu } \\
\text { - }\end{array}$ & $\begin{array}{l}\text { GD } \\
P \\
\text { per } \\
\text { cap } \\
\text { ita }\end{array}$ & $\begin{array}{l}\text { Gl } \\
\text { ob } \\
\text { al } \\
\text { Tr } \\
\text { ad } \\
\text { e } \\
(\$ \\
\text { Bn } \\
)\end{array}$ & $\begin{array}{l}\text { Int } \\
\text { ra- } \\
\text { Af } \\
\text { ric } \\
\text { a } \\
\text { Tr } \\
\text { ad } \\
\text { e } \\
(\$ \\
\text { Bn } \\
)\end{array}$ & $\begin{array}{l}\text { Glo } \\
\text { bal } \\
\text { Tra } \\
\text { de } \\
\text { Bal } \\
\text { anc } \\
\text { e } \\
\text { (\$B } \\
\text { n) }\end{array}$ & $\begin{array}{l}\text { Int } \\
\text { ra- } \\
\text { Afr } \\
\text { ica } \\
\text { Tra } \\
\text { de } \\
\text { bal } \\
\text { anc } \\
\text { e } \\
\text { (\$B } \\
\text { n) }\end{array}$ \\
\hline $\begin{array}{l}\text { ECO } \\
\text { WA } \\
S\end{array}$ & $\begin{array}{l}565 \\
.09\end{array}$ & $\begin{array}{l}24 . \\
9 \%\end{array}$ & 359.8 & $\begin{array}{l}28 . \\
9 \%\end{array}$ & $\begin{array}{l}1,5 \\
37 . \\
40\end{array}$ & $\begin{array}{l}16 \\
5.9\end{array}$ & $\begin{array}{l}25 . \\
9\end{array}$ & 48 & 5 \\
\hline $\begin{array}{l}\text { SAD } \\
\mathrm{C}\end{array}$ & $\begin{array}{l}680 \\
.02\end{array}$ & $\begin{array}{l}30 . \\
0 \%\end{array}$ & 316.9 & $\begin{array}{l}25 . \\
4 \%\end{array}$ & $\begin{array}{l}2,1 \\
46 . \\
70\end{array}$ & $\begin{array}{l}32 \\
7.1\end{array}$ & $\begin{array}{l}73 . \\
4\end{array}$ & $\begin{array}{l}18 . \\
4\end{array}$ & 2 \\
\hline EAC & $\begin{array}{l}169 \\
.66\end{array}$ & $\begin{array}{l}7.5 \\
\%\end{array}$ & 185.5 & $\begin{array}{l}14 . \\
9 \%\end{array}$ & $\begin{array}{l}914 \\
.5\end{array}$ & $\begin{array}{l}45 . \\
7\end{array}$ & 9.8 & $\begin{array}{l}- \\
18 . \\
5\end{array}$ & 0.9 \\
\hline $\begin{array}{l}\text { UM } \\
\text { A }\end{array}$ & $\begin{array}{l}360 \\
.35\end{array}$ & $\begin{array}{l}15 . \\
9 \%\end{array}$ & 99.4 & $\begin{array}{l}8.0 \\
\%\end{array}$ & $\begin{array}{l}3,6 \\
25 . \\
00\end{array}$ & $\begin{array}{l}22 \\
1.1\end{array}$ & $\begin{array}{l}11 . \\
1\end{array}$ & -28 & 0.6 \\
\hline $\begin{array}{l}\text { ECC } \\
\text { AS }\end{array}$ & $\begin{array}{l}180 \\
.74\end{array}$ & $\begin{array}{l}8.0 \\
\%\end{array}$ & 89.5 & $\begin{array}{l}7.2 \\
\%\end{array}$ & $\begin{array}{l}2,0 \\
19 . \\
00\end{array}$ & $\begin{array}{l}54 . \\
7\end{array}$ & $\begin{array}{l}12 . \\
1\end{array}$ & 6.5 & -1.7 \\
\hline $\begin{array}{l}\mathrm{CO} \\
\mathrm{MES} \\
\mathrm{A}\end{array}$ & $\begin{array}{l}714 \\
.56\end{array}$ & $\begin{array}{l}31 . \\
5 \%\end{array}$ & 528.7 & $\begin{array}{l}42 . \\
4 \%\end{array}$ & $\begin{array}{l}1,3 \\
51 . \\
50\end{array}$ & $\begin{array}{l}23 \\
7.3\end{array}$ & $\begin{array}{l}35 . \\
6\end{array}$ & $\begin{array}{l}- \\
66 . \\
4 \\
\end{array}$ & -6.2 \\
\hline $\begin{array}{l}\text { Afri } \\
\text { ca } \\
\text { (Tot } \\
\text { al) }\end{array}$ & $\begin{array}{l}226 \\
6.6 \\
8\end{array}$ & $\begin{array}{l}\mathbf{1 0} \\
0 \\
\%\end{array}$ & $\begin{array}{l}1246 . \\
2\end{array}$ & $\begin{array}{l}10 \\
0 \\
\%\end{array}$ & $\begin{array}{l}181 \\
8.9\end{array}$ & $\begin{array}{l}93 \\
0.6 \\
5\end{array}$ & $\begin{array}{l}13 \\
5.4\end{array}$ & $\begin{array}{l}- \\
77 . \\
7\end{array}$ & 6.5 \\
\hline
\end{tabular}

Source: Guobadia (2017).

The cause and effects of the trends and profile of health outcomes (infant mortality, US-MR and maternal mortality) and index of economic globalization (trade openness and capital inflow, FDI) over the reviewing period is presented in Figure 2.1. 
Fig.1: Trend of Economic globalization and health outcomes in Nigeria

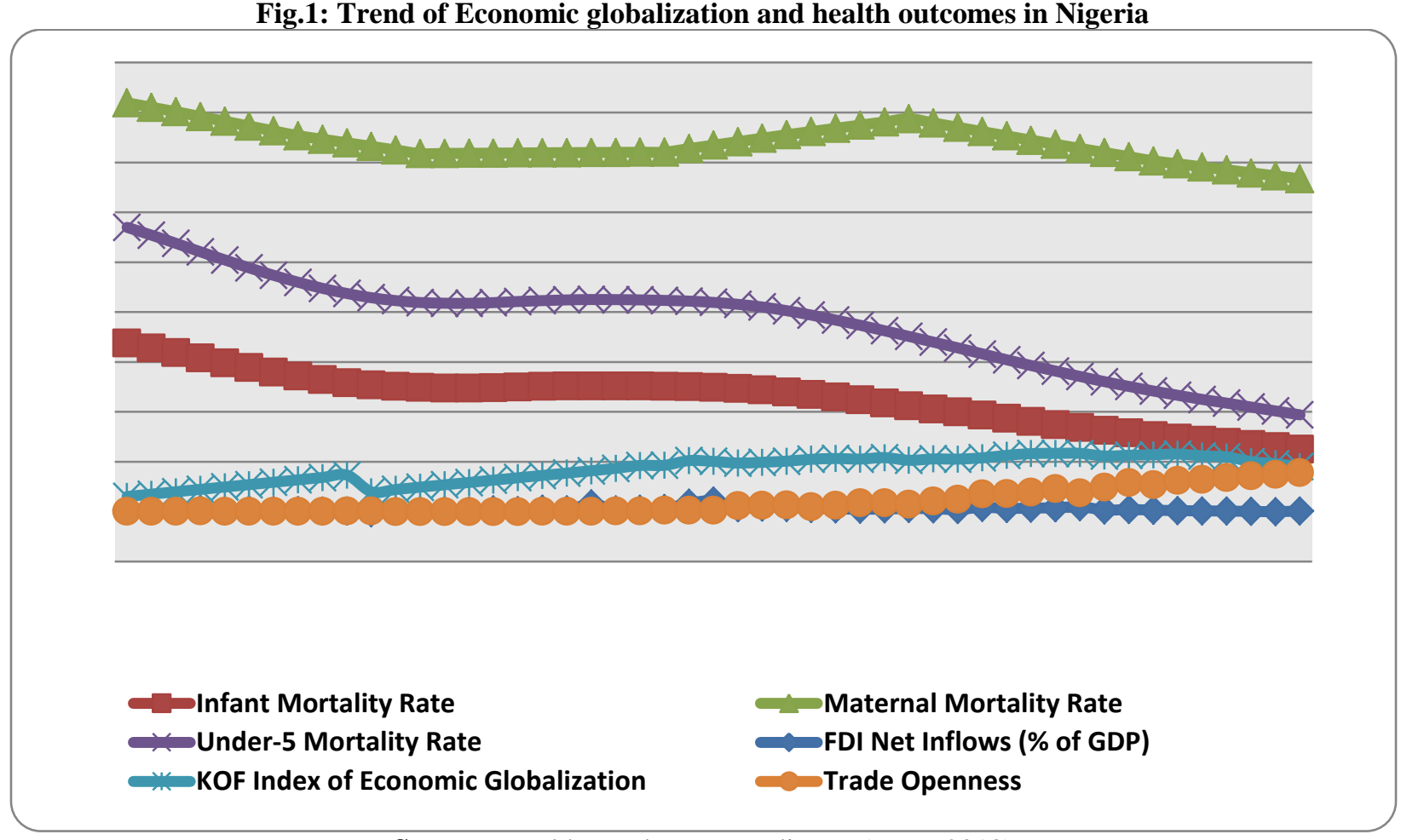

Source: World Development Indicator (WDI, 2018)

\section{LITERATURE REVIEW}

\subsection{Conceptualizations}

To identify the key determinants of health outcomes in poor countries both at the national, and for rural and urban areas separately, Wang (2002) focused on two health indicators of the infant mortality rate (IMR) and the under-five mortality rate (U5MR). The author asserted further that child mortality rates are generally regarded as the principle measures of a country's level of health status. Life expectancy is another important indicator, but its estimates is also based on the mortality rate, although more comprehensive measures would include indicators measuring mortality. However, the latter measures tend to be less reliable and in most cases, are less comparable across countries.

Anand and Barnighausen (2004) focused on the standard measures of maternal, infant and under-five mortality rates as the population health outcomes. According to the authors, all the three have been incorporated as indicators of the United Nations Millennium Development Goals (MDGs). Anyanwu and Erhijakpor (2007) used infant mortality and under-five mortality rates as measures of health outcome. Accordingly, these indicators have been consistently available for most African countries. From the foregoing on conceptual review, it can be deduced that infant mortality and under-five mortality is the acceptable measure of health outcome in the literature and therefore should form the conceptual framework of the current study.

\section{b. Economic Globalization}

This publication is licensed under Creative Commons Attribution CC BY.

http://dx.doi.org/10.29322/IJSRP.10.10.2020.p10671
Defining and measuring globalizations seems too complex following two points of observations: First, there is not a single, general accepted definition of globalization, as the wide range of indicators tries to reflect the complexity of the process-economic, social, political, technological and cultural dimensions of globalization which have been reflected separately or aggregated through indexes and globalization impact scale (Marginean, 2015). Second, is the changing character of the complex process of globalization, following the crisis effects and dramatic collapse of international trade and foreign direct investment, the two main drivers of globalization.

In 2010, Organization for Economic Cooperation and Development (OECD) second edition book on economic globalization indicators provided a comprehensive selection of the main dimensions of economic globalization measures. The book covers indicators that can measure the magnitude and intensity of globalization: (i) globalization of trade and investment; international trade of goods and services; foreign direct investment; portfolio investment; (ii) globalization of technology and knowledge (iii) multinational enterprises, (iv) global value chain (OECD, 2010). According to the Maastricht Globalization Index (MGI) proposed by Pim Martens (Marten, 2012), there are five dimensions of globalization: Political, economic and cultural, technological and ecological. Economic globalization is evaluated based on the stocks as a share of GDP); capital (Gross private flows as a share of GDP). Meanwhile, the ATK Globalization index (ATK-GI) covers four dimensions of globalization process (Keaney \& FP, 2007): political engagement, personal contacts, technological connectivity and economic integration. These indicators used for 
evaluating these four dimensions are: political engagement: foreign aid, treaties, organizations and peacekeeping; personal contact: telephone calls, travel and remittances; technological connectivity: number of internet users, hosts, secure servers; economic integration: international trade and foreign direct investment. All of them include both micro and macro dimensions of economic globalization. The Globalization Index of A.T. Kearney/Foreign Policy (2002) was probably the first attempt to construct a composite measure of globalization. It categories 14 indicators into the four dimensions of economic integration, personal contact, technology, and political engagement. Several other composite measures followed, including the G-Index (Randolph, 2001), (SGR Globalization Index (Lockwood \& Redoano, 2005), Maastricht Globalization Index (Martens \& Zywietz, 2006), and KOF Index of Globalization (Dreher, Gaston \& Martens, 2008). While these indexes differ in the number of countries analyzed, years covered, indicators, and weighting schemes utilized, each of them combines data on a country-by-country basis into one aggregate to measure globalization. Hug and Cyn (2019) constructed a new index of globalization, Global Economic Integration Index (GEII) based on 25 variables for 158 countries over the period 2006-2014. The key difference from existing composite measures of globalization is that the GEII can be decomposed into regional and non-regional integration. The GEII can assess the relative contributions of intra-regional and extra regional integration to globalization. This can be useful for assessing the role of regional integration in relation to globalization and informing national and international policy decisions about how best to manage economic integration at different layers of geographic groupings, given its potential risks and weaknesses.

From the foregoing, and aligning with the assertions of Popoola (2018), over the last three decades, economic globalization (which is often characterized by international trade and finance) has been the key driving force behind the overall process of globalization both developed and developing economies. The figure 2 sketches the conceptual framework for globalization and health outcomes. The framework provides a basis for comprehensive cases studies of the impact of globalization on health or its effects on a particular health problem or determinants of health.

Figure 2: Conceptualizing globalization and Health outcomes

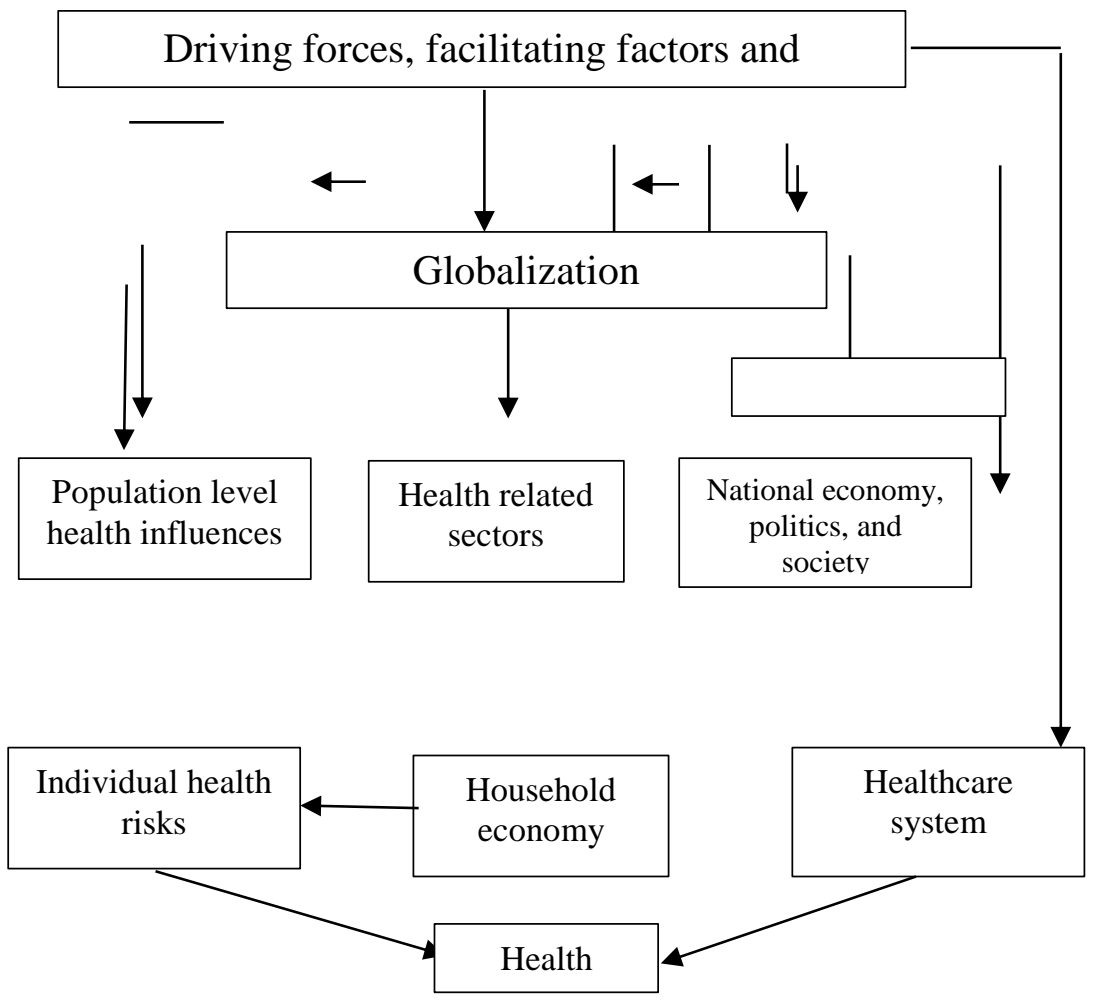

Sources: Woodward et al (2001)

\subsubsection{Empirical Literature}

There are related studies on the focus of the study. For example, Welander, Lyttkens and Wilson (2014) examined the impact of globalization and the role of democracy child health outcomes in, 70 developing countries between 1970 and 2009. The variables used are child health, globalization, democracy and a dummy variable, capturing policy variations. The panel data estimation approach was used. The results suggested that globalization reduces infant mortality and that the level of democracy in a country generally improves child health outcomes. The results further revealed that democracy matters for the size of the globalization effect on child health. 
Owen and $\mathrm{Wu}$ (2007) investigated the relationship between trade openness and health. The variables used are trade as a share of GDP, Sachs-Warner Index (1995), black market premium, male and female life expectancy at birth and the infant mortality rate. The fixed effects estimations technique between the periods 1960-1995 were used on 219 low-, middle and high-income countries. The results revealed that trade openness is positively related to health and the relationship is stronger in low-income counties than other countries. The mechanisms seem to be knowledge spillovers and sound macroeconomic policies that are positively correlated with trade openness policies that are positive for health.

Tsai (2007) examined globalization and human well-being. The KOF index of globalization and its three dimensions and the Human Development Index (HDI) were used. The random effects estimation technique was employed on data set between 1980-2000 for 112 low, middle-and high-income countries. The results show that overall, economic globalization and political globalization are positively related to HDI and that the effect appeared stronger in high income countries than low income countries.

Bergh and Nilsson (2010) explored the correlation between globalization and health using KOF index and its three dimensions, total male and female life expectancy at birth. The panel corrected standard errors (PCSE) procedure with country and period dummies and fixed effects estimations were used between the period 1970-2005 on 92 low-middle- and highincome countries. The result showed that overall other globalization dimensions and economic globalization increases life expectancy.

Mukherjee and Krieckhaus (2011) investigated the nexus between globalization and health in 132 low-, middle-and highincome countries, between 1970-2007 using the fixed effects estimations technique. The variables used are the KOF index and its three dimensions, total life expectancy at birth, the infant and child mortality rates. The result revealed that overall, political globalization, and economic and social globalization positively relates to health outcome. This also holds for a sample of only non-OECD countries.

Popoola (2018) examined the impact of economic globalization and life expectancy in Nigeria between the 1986 to 2016 using the Johansen cointegration approach. The variables used are life expectancy at birth; trade and FDI. The findings showed that economic globalization have positive and significant impact on life expectancy in Nigeria.

Fatile and Adesanya (2016) examined the effect of globalization on Health care service delivery in Lagos University State Teaching Hospital (LUTH) using the questionnaire approach and in-depth interview technique. The findings revealed that there is a strong relationship between structures of globalization and health care service delivery in LASUTH.

Riman and Akpan (2012) examined the relationship between healthcare financing and Health outcomes in two rural local government area and one urban local government area of Cross River State, Nigeria. The study demonstrated that the high levels of infant mortality and morbidity rate was associated with the high incidence of out-of-pocket payment, and the wide disparity and inequality in income distribution. The study further observed a disproportionate disparity in the spatial distribution of health facilities, with concentration of health facilities at the urban areas rather than the rural areas, which of course contributed to the poor service demand.

Imo, Isiugo-Abanihe and Chikezie (2017) examined socioeconomic determinants of under-five children health outcome with data from a sample of 609 women of childbearing age in rural and urban areas of Abia State. The multi-stage sampling technique were utilized. The study showed that the outcome of an under-five child's health depends on socio-economic factors.

Levine and Rothman (2006) focused on the impact of trade openness on child health. The authors reported a coefficient of 0.63 , which implies that a $1 \%$ increase in trade openness would lead to about more than half a year reduction in infant mortality.

Hudak (2014) explored the relationship between trade openness and differential health outcomes, considering a panel data set of thirty low and high income countries from 1960 to 2012. Using the random effect estimation technique, results from the study indicate that at $10 \%$ significance level, an increase in trade openness leads to $14.09 \%$ increase in life expectancy.

Stevens, Urbach and Wills (2013) studied the relationship between free trade and health. The empirical findings revealed that free trade is correlated with better health and this becomes clearer when dealing with low income countries. Using the synthetic control method to estimate the effects of trade liberalization on health outcomes for the periods of 1960 to 2010 in South Africa, Olper et al., (2014) found a significant short-run and long-run reduction in child morality by trade liberalization. Herzer (2014) also estimated that long-run relationship between trade and population health using a panel time series data from 1960-2010 for seventy-four (74) developed and developing countries. The study found a positive relationship between life expectancy and trade openness while a negative relationship between infant mortality and trade openness existed. The paper therefore concluded that trade openness has positive and significant impact on population health. It also found a long-run causality running from both directions.

The empirical evidence highlighted the trend of research on the subject matter. However, despite the growing studies on globalization and health outcomes in developing countries, there is no agreement on the effects of globalization on health status. While some studies evidenced the hazards of globalization on health status (Ajayi \& Garba, 2008) through infectious diseases transmitted through fake drugs, other studies showed improvement in health outcome through access to health facilities and technology (Martens, Akin, Huynen \& Raza, 2010. In conclusion, the effects of globalization on health outcome is mixed.

\section{METHODOLOGY AND DATA}

\subsection{Theoretical Framework}

The theoretical framework of the study is anchored on the Grossman (1972) demand for health production function. Following Grossman, Fayissa and Gutema (2008) theoretical production function given as follows:

$$
\mathrm{H}=\mathrm{f}(\mathrm{X})
$$

Where $\mathrm{H}=$ Individual health output/outcome, $\mathrm{X}=$ vector of individual inputs to the health production function, f. The 
elements of the vector include nutrient intake, income, consumption of public goods, education, time devoted to health related procedures, initial health stock and the environment. The above model represents the micro health production analysis. To account for macro level health production, Fayissa and Gutema (2008) presented a macro level specification of equation (4.1) by representing the elements of the vector $X$ as per capita variables and then regrouped them into sub-sector vectors of social, economic and environmental factors. The macro level health production health function is represented in the equation as:

$$
\mathrm{h}=\mathrm{f}(\mathrm{Y}, \mathrm{S}, \mathrm{V})
$$

\section{2}

where $\mathrm{h}$ is the aggregate population health status outcome, $\mathrm{Y}$ is a vector of per capita economic variables, $\mathrm{S}$ is a vector of per capita social variables and $\mathrm{V}$ is also a vector of per capita environmental factors. In the study, we introduce economic globalization variable as a component of the economic variable in the theoretical formulation and re-specified the model.

\subsection{The Model}

To be able to provide estimates for the parameters of the study, an econometric specification of the model to be used is necessary. From the theoretical model, globalization and population health status function takes the reduce form as follows:

LnPHS $=\alpha_{0}+\alpha_{1} \operatorname{lnKoF}+\alpha_{2} \ln$ RGDP $+\alpha_{3} \ln$ HELINFR + $\alpha_{4} \operatorname{lnODA}+\alpha_{5} \ln$ POPR $+\alpha_{6} \ln$ SANITA $+\alpha_{7} \ln$ GOVHEXP $+\mathrm{e}$

\section{4}

where PHS = population health status (proxy, infant mortality rate); $\mathrm{KOF}=$ index of economic globalization (trade openness and foreign direct investment); RGDP = real gross domestic product (a proxy for the economy); HELINFR $=$ health infrastructure. ODA = overseas development assistance (donor aid to health sector financing mechanism); SANITA = access to sanitation and PPOR = population growth, e = error term and $\mathrm{Ln}=$ the natural logarithms.

\subsection{Data Sources}

The study employed annual time series data from 19702018 for Nigeria. The description of the variables is provided in Table 1 .

Table 3: Description of Variables of the Model

\begin{tabular}{|l|l|l|}
\hline Variables & Description & Sources \\
\hline INFMOR & $\begin{array}{l}\text { Infant mortality rate } \\
\text { (Dependent variable) }\end{array}$ & WDI, 2018 \\
\hline KOFIND & $\begin{array}{l}\text { KOF Index of } \\
\text { Economic } \\
\text { globalization (trade } \\
\text { openness FDI and } \\
\text { foreign portfolio } \\
\text { inflow) }\end{array}$ & \\
\hline RGDP & $\begin{array}{l}\text { Real gross domestic } \\
\text { product, proxy for the } \\
\text { economy }\end{array}$ & $\begin{array}{l}\text { CBN Statistical } \\
\text { Bulletin (Various } \\
\text { Years) }\end{array}$ \\
\hline HELINFR & $\begin{array}{l}\text { Health Infrastructure } \\
\text { (proxy, hospital beds) }\end{array}$ & WDI (2018) \\
\hline ODA & Overseas Development & WDI (2018) \\
\hline
\end{tabular}

This publication is licensed under Creative Commons Attribution CC BY.

http://dx.doi.org/10.29322/IJSRP.10.10.2020.p10671

\begin{tabular}{|l|l|l|}
\hline & $\begin{array}{l}\text { Assistance (donor } \\
\text { health financing) }\end{array}$ & \\
\hline POPR & Population growth & WDI (2018) \\
\hline SANITA & $\begin{array}{l}\text { Access to clean water } \\
\text { health }\end{array}$ & WDI (2018) \\
\hline GOVHEXP & $\begin{array}{l}\text { Government } \\
\text { expenditure on health }\end{array}$ & WDI (2018) \\
\hline
\end{tabular}

Note: WDI - World Development Indicator

$\mathrm{CBN}=$ Central Bank of Nigeria Statistical Bulletin of various years.

In accordance with the literature, health expenditure as an indicator of the volume of resources flowing into health is expected to have negative effect on infant mortality rates, thus an increase in health expenditure implies a broader access to healthcare and services which helps to decrease infant mortality rates. Given the redistributive effect of public intervention, a positive correlation between public financing and health outcome is expected (Anyanwu \& Erhijakpor, 2007). However, as shown by Herzer (2014), there is a negative relationship between infant mortality and trade openness, one of the indicators of economic globalization. In addition, as Herzer, Korbiniah and Peter (2015) had shown, the relationship between FDI and health is nonlinear, depending on the level of income. FDI has a positive effect on health at low level of income, but the effect decreases with increasing income. As posited by Bloom, Kuhn and Prettner (2018), the underlying mechanisms of the correlation between health and economic growth are complex and difficult to predict. First, the causality between health and economic growth is challenging. Second, the relation between health and economic growth changes the process of economic development and the different dimensions of health (mortality vs. morbidity, children's and women's health, and health at older ages) may have different economic effects. Following theoretical and empirical literature, we expect a positive relationship between health infrastructure and measure by bed space.

Sadck (2012) found a statistically significant and positive effect of aid on infant mortality, as doubling of aid leads to an approximately $1.3 \%$ reduction in infant mortality rates in 135 countries between 1975 and 2010 examined. Similarly, Prachi and David found out that aid has a statistically significant effect on infant mortality in 118 countries examined between 1973 and 2004 as such, doubling per capita health aid is association with a 2 percent reduction in the infant mortality rate. We therefore expect a positive and significant relationship between the index of globalization and public health outcomes within the reviewing period.

Lakshmi and Sahoo (2013) established a negative relationship between health infrastructure and health indicator in the case of Andhra Pradesh, India, such that the elasticity coefficient of health indicators like crude birth rate, crude heath rate, infant mortality and life expectancy at birth with respect to health infrastructure are $-37.966,-27.816,-30.598$ and 10.282 respectively. Meanwhile, Hati and Majumder (2013) posited a strong relation between primary health infrastructure and preventive and curative health achievements. Therefore, the coefficient of health infrastructure on health outcome is expected to be positive.

Fertility, migration and urbanization affect the spread of diseases including tuberculosis, malaria and HIV/AIDS. 
Increased population densities and unhealthy living conditions in urban slums can ease the transmission of infections. Migrations may also increase vulnerability to disease (Population Action International, 2012). We anticipated a negative relationship between growth in population and health outcomes. Limited access to sanitation infrastructure, poor hygienic practices, and unsafe drinking water negatively affect the health of millions of people in the developing world. Using sanitation interventions to interrupt disease pathways can significantly improve public health outcomes. Sanitation interventions primarily benefit public health by reducing the prevalence of enteric pathogenic illnesses, which cause diarrhea (Lipson, Anderson \& Bolton, 2010; Wolfgang et al., 213; Bouzid et al., 2018). We expect the coefficient of sanitation to be positively and significantly related to health outcomes.

\subsection{Estimation Technique}

First, we check for the characteristics and movements of the variables using the descriptive statistics and correlation matrix. This is followed by the time series properties of the variables. We check stationarity of the series using Philip-Peron (PP) and Augmented Dickey Fuller at level and first difference to avoid spurious results. If the variables are found to be order of I(1) or say non-stationary, there may be chancing of forming I(0) variable. This is called cointegration test which means testing for long-run relationship among the variables of the model. If the variables under study are cointegrated, the cointegrating vector is normalized with respect to public health outcomes. To test whether cointegration exists or not, we apply the systems method of cointegration proposed by Johansen and Juselius (1992). This enables the usage of the vector error correction model (VECM). The appropriate specification for the error-correction model will be:

$$
\Delta \mathrm{Y}_{\mathrm{t}}=\frac{\beta_{\mathrm{o}}+\beta_{1} \Delta \mathrm{X}_{\mathrm{t}}+\lambda u_{\mathrm{t}-1}+\mathrm{e}_{\mathrm{t}}}{4.3}
$$

Or,

$\Delta \mathrm{Y}_{\mathrm{t}}=\beta_{\mathrm{o}}+\beta_{1} \Delta \mathrm{X}_{\mathrm{t}}+\lambda\left(\mathrm{Y}_{\mathrm{t}-1}-\alpha_{\mathrm{o}}-\alpha_{1} \mathrm{X}_{\mathrm{t}-1}\right)+\mathrm{e}_{\mathrm{t}}$ 4.4

The $\tau_{\mathrm{t}-1}$ term is the magnitude by which y was above or below its long-run equilibrium value in the previous period. The coefficient $\lambda$ (which we expected to be negative) represents the amount of "correction" of this period (t-1) disequilibrium that happens in period $\mathrm{t}$.

\section{RESULTS AND INTERPRETATION}

\subsection{Summary of Descriptive Statistics}

The summary of descriptive statistics of infant mortality (proxy for health outcome), index of economic globalization (KOFIND), real gross domestic product (RGDP), health infrastructure (HELINFR), overseas development assistance (ODA), population growth rate (POPR) and access to sanitation (SANITA) variables included in the model are reported in Table 5.1. The statistics indicate the existence of wide variations in the variables. For instance, the average INFMOR for the 1970-2018 period was 113.88 percent, compared to 42.60 percent, 1.37 percent, 0.85 percent, 2.6 and 44.34 percent respectively for KOFIND, HELINFR, ODA, POPR and SANITA.

Table 4: Descriptive Statistics (1970-2018)

\begin{tabular}{|l|l|l|l|l|l|l|l|}
\hline & INFMOR & KOFIND & REALGDP & HEL/NFR & ODA & POPR & SANITA \\
\hline Mean & 113.8755 & 42.60180 & 393607.3 & 1.375804 & 0.859115 & 2.607276 & 44.33776 \\
\hline Median & 123.9000 & 48.03922 & 275450.6 & 0.742040 & 0.514087 & 2.582376 & 44.800000 \\
\hline Maximum & 168.9000 & 58.44728 & 1239342 & 6.370300 & 8.117241 & 3.048043 & 71.36667 \\
\hline Minimum & 62.76667 & 15.20503 & 4219.000 & 0.342000 & 0.054814 & 2.293336 & 15.33000 \\
\hline Std Dev. & 26.92365 & 13.32031 & 351180.7 & 1.452929 & 1.416226 & 0.151628 & 16.93553 \\
\hline Skewness & -0.217807 & -0.552292 & 0.915721 & 2.009993 & 4.126110 & 0.993633 & -0.064516 \\
\hline Kurlosis & 2.406774 & 1.893879 & 2.788518 & 6.244659 & 19.99145 & 4.677000 & 1.773515 \\
\hline Jarque-Bera & 1.105925 & 4.989033 & 6.939426 & 54.48820 & 728.4842 & 13.80485 & 3.105263 \\
\hline Probability & 0.575243 & 0.082536 & 0.031126 & 0.000000 & 0.000000 & 0.001005 & 0.211690 \\
\hline Sum & 5579.900 & 2087.488 & 19286759 & 67.41440 & 42.09665 & 127.7565 & 2172.550 \\
\hline Sum Sq. Dev. & 34794.38 & 8516.674 & $5.92 \mathrm{E}+12$ & 101.3281 & 96.27341 & 1.103563 & 13766.98 \\
\hline Observations & 49 & 49 & 49 & 49 & 49 & 49 & 49 \\
\hline
\end{tabular}

Note: INFMOR $=$ infant mortality rate, KOFIND $=$ Index of economic globalization (openness of trade and FDI); REAL GDP = economic growth proxy; ODA $=$ foreign aid POPR $=$ Population growth; SANITA $=$ Access to sanitation; HELINFR $=$ health infrastructure.

Source: Author's Computation using EVIEW 10.0

The statistics in table 5.1 showed that the average value of INFMOR stood at 113.87; $43 \%$ for KOFIND; 393607 for real GDP; $1 \%$ for health infrastructure; $0.86 \%$ for foreign aid; $2.6 \%$ for population growth rate and $44 \%$ for access to sanitation. The table 5.1 further indicates that the values ranges from $62-168$ for INFMOR; 15-58 for KOFIND; 4219-1239342 for real GDP; 0-6 for health infrastructure; $0-8$ for foreign aid; $2-3$ for population growth; and 15-71 for access to sanitation. The table 4 further revealed that informant mortality and index of economic globalization were negatively and significantly skewed to 0.217807 and -0.552292 respectively while the other variables 
were positively and significantly skewed within the reviewing period 1970-2018.

Table 5: Correlation Matrix

\begin{tabular}{|l|l|l|l|l|l|l|l|}
\hline & LKOFIND & LREALGDP & LHELINFR & LODA & LPOPR & LSANITA & LGOVHEXP \\
\hline LKOFIND & 1.00000 & 0.859463 & -0.197856 & 0.460346 & 0.092 & 0.918 & 0.890 \\
\hline LREALGDP & 0.859463 & 1.000000 & -0.057326 & 0.267440 & 0.062 & 0.96 & 0.894 \\
\hline LHELINFR & -0.197856 & -0.057326 & 1.000000 & -0.225543 & -0.1156 & -0.242 & -0.44 \\
\hline LODA & 0.460346 & 0.267440 & $5543-0.22$ & 1.000000 & -0.507 & 0.379 & 0.402 \\
\hline LPOPR & 0.092506 & 0.062926 & -0.115671 & -0.507233 & 1.0000 & 0.018 & 0.03 \\
\hline LSANITA & 0.918996 & 0.961713 & -0.242712 & 0.379027 & 0.0188 & 1.000 & $0.97^{*}$ \\
\hline LGOVHEXP & 0.890422 & 0.894780 & -0.441251 & 0.402191 & 0.030 & 0.974 & 1.000 \\
\hline
\end{tabular}

Note: KOFIND = Index of economic globalization; REAL GDP = economic growth proxy; HELINFR = health infrastructure; ODA = foreign aid; POPR = population growth; SANITA = Access to sanitation; GOVHEXP $=$ Government health expenditure; $\mathrm{L}=$ natural logarithm.

Source: Authors' Computation using EVIEW 10.0

The matrix showed that with the exception of SANITA; GOVHEXP and REALGDP, the other variables are within the standard of non- multicollinearity indicated by $0.95 \%$ following (Iyoha, $2009 \&$ Tella,2018). However, our unit root result of order one, I(1) will suppress the negative effect of multicollinearity in the model (Stock \& Watson, 2007).

Table 6: Unit Root Test

\begin{tabular}{lllll}
\hline Variables & \multicolumn{3}{l}{ PP Test Statistics } & ADF \\
\cline { 2 - 5 } & Level $[\mathrm{I}(0)]$ & $1^{\text {st }}$ Difference & Level $[\mathrm{I}(0)]$ & $1^{\text {st }}$ Difference \\
\cline { 2 - 5 } LKOFMOR & $-1.0401(0.99)$ & $-1.1371(0.69)^{ \pm}$ & $4.311(1.000)$ & $-2.91(0.05)^{*}$ \\
LKOFIND & $-2.88(0.5)$ & $-6.587(0.000)^{* * *}$ & $-2.87(0.05)^{*}$ & $-6.59(0.00)^{* * *}$ \\
LREALGDP & $-5.22(0.00)^{* * *}$ & $-6.384(0.000)^{* * *}$ & $-2.54(0.11)$ & $-1.98(0.29)^{ \pm}$ \\
LHELINFR & $-1.101(0.708)$ & $-3.600(0.00)^{* * *}$ & $-1.43(0.56)^{ \pm}$ & $-3.52(0.00)^{* *}$ \\
LODA & $-2.1068(0.24)^{ \pm}$ & $-6.055(0.000)^{* * *}$ & $-1.97(0.29)^{ \pm}$ & $-5.76(0.00)^{* * *}$ \\
LPOPR & $-2.806(0.06)^{*}$ & $-2.511(0.11)^{ \pm}$ & $-2.96(0.04)^{* *}$ & $-3.82(0.05)^{* * *}$ \\
LSANITA & $-2.806(0.06)^{* * *}$ & $-11.23(0.000)^{* * *}$ & $-4.46(0.00)^{* * * *}$ & $-4.84(0.00)^{* * * *}$ \\
LGOVHEXP & $-1.362(0.59)^{ \pm}$ & $-7.76(0.000)^{* * *}$ & $-1.75(0.39)^{ \pm}$ & $-3.22(0.02)^{* * *}$ \\
\hline
\end{tabular}

Note: $(*)$ significant at the $10 \% ;(* *)$ significant at the $5 \% ;(* * *)$ significant at the $1 \%$ and ${ }^{ \pm}$Not significant.

Source: Authors' Computation using E-view 10.0

Table 6 showed the results of the stationarity test of the variables of the model. It revealed that majority of the variables were stationary at the first difference,1(1) at both the PhilippPeron and Augmented Dickey Fuller test at the denoted level of significance. The satisfactory unit root test results lead to the further confirmation of the time series properties of the variables using the Johansen cointegration rank test and the normalized cointegration coefficients as reported in Table 5.4 and 5.5.

Table 7: Cointegration Rank Test

\begin{tabular}{|l|l|l|l|l|l|}
\hline Johansen and Julius Maximum Likelihood Cointegration Rank Tests \\
\hline Eigen value & Trace statistic & Max statistic & $\begin{array}{l}\text { CV @ 5\% } \\
\text { Trace }\end{array}$ & CV @ 5\% Max & $\begin{array}{l}\text { Hypothesized } \\
\text { No of CE(s) }\end{array}$ \\
\hline 0.906261 & 398.3874 & 108.8931 & 159.52 & 52.36 & None* \\
\hline 0.848748 & 289.4943 & 86.88516 & 125.62 & 46.23 & At most $1^{*}$ \\
\hline 0.799641 & 202.6092 & 73.95176 & 95.75 & 40.07 & At most $2^{*}$ \\
\hline 0.672149 & 128.6574 & 51.29867 & 47.86 & 33.87 & At most $3^{*}$ \\
\hline 0.585119 & 77.35874 & 40.46916 & 29.79 & 27.58 & At most $4^{*}$ \\
\hline 0.428302 & 36.88957 & 25.72062 & 15.49 & 21.13 & At most 5* \\
\hline 0.211477 & 11.16896 & 10.92932 & 3.84 & 14.26 & At most 6 \\
\hline 0.005196 & 0.239633 & 0.239623 & 69.81 & 3.84 & At most 7 \\
\hline
\end{tabular}

Note: * denotes rejection of the hypothesis at the 0.05 level. 
Source: Authors' Computation using the E-VIEW 10.0

The cointegration test of Johansen \& Juselius revealed 6 cointegrating eqn.(s) at the 0.05 level of significance for both the Trace and Max-Eigen Statistics. The implication is that there exist long-run equilibrium relationship for the variables of the model. Table 5.5 revealed the long-run normalized coefficients, the results indicates the magnitude and pattern of long-run equilibrium behavior of our model.

Table 8A: Normalized Cointegrating Coefficients

\begin{tabular}{llllllll}
\hline LINFMOR & LKOFIND & LREALGDP & LHELINFR & LODA & LPOPR & LSANITA & LGOVHEXP \\
1.000000 & 1.470863 & 1.970740 & -0.114383 & -0.176585 & -8.81 & -0.83 & -0.053 \\
& $(0.33)$ & $(0.145)$ & $(0.090)$ & $(0.035)$ & $(1.115)$ & $(1.059)$ & $(0.120)$ \\
\hline
\end{tabular}

Note: Normalized cointegrating coefficients (standard error in parentheses)

Source: Authors' Computation using EVIEW 10.0

Table 8B: Normalized Cointegrating Coefficients

\begin{tabular}{llllllll}
\hline LINFMOR & LKOFIND & LREALGDP & LHELINFR & LODA & LPOPR & LSANITA & LGOVHEXP \\
1.000000 & 0.000000 & 0.911542 & -0.175637 & -0.073568 & -4.642 & -1.121 & 0.114 \\
& & $(0.06362)$ & $(0.04839)$ & $(0.01660)$ & $(0.597)$ & $(0.549)$ & $(0.063)$ \\
0.000000 & \multirow{2}{*}{1.000000} & 0.720120 & 0.041645 & -0.07003 & -2.837 & 0.197 & -0.114 \\
& & $(0.04143)$ & $(0.03151)$ & $(0.01081)$ & $(0.389)$ & $(0.35)$ & $(0.04)$ \\
\hline
\end{tabular}

Source: Author's Computation using EVIEW 10.0

Tables $8 \mathrm{~A}$ and $8 \mathrm{~B}$ revealed the results of the normalized cointegrating coefficients. From the first panel 8A), the coefficients of KOFIND and REALGDP appeared positive in line with the theoretical postulations/behavioural restrictions in both Tables. The coefficients of health infrastructure showed negative relationship with health outcome as expected theoretically in both panels. These results are in tandem with the earlier findings of Lakshni et al. (2013) for Andra Pradesh, India. The coefficients of foreign assistance (aid) was negative against the theoretical postulation and findings of $\operatorname{Sadek}(2012)$ for the
135 countries examined and the findings of Prachi and David(2014) for 118 countries examined. The negative relationship between foreign aid and health outcome could be linked to aid fungibility in developing countries, Nigeria inclusive. Population growth has a negative relationship with health outcome as theoretical expected. Furthermore, access to sanitation appeared negative against the expectations and government expenditure appeared negative as expected. The vector error correction (VECM) estimate re reported in Table 9

Table 9: Equilibrium Vector Error Correction

\begin{tabular}{llllllll}
\hline Variable & LINFMOR & LKOFIND & LREALGDP & LHELINFR & LODA & LPOPR & LSANITA \\
Coint Eq1 & -0.000555 & 0.11880 & -0.526935 & -0.016882 & 0.780405 & 0.005293 & -0.00075 \\
& $(0.00121)$ & $(0.07587)$ & $(0.10312)$ & $(0.13367)$ & $(0.47443)$ & $(0.00245)$ & $(0.00075)$ \\
& {$[-0.45652]$} & {$[1.56598]$} & {$[-5.10915]$} & {$[-0.12629]$} & {$[1.64493]$} & {$[2.15751]$} & {$[-1.01288]$} \\
\hline
\end{tabular}

Source: Authors' Computation using EVIEW 10.0

The coefficients of ECM (-1) as seen in Table 9 conforms with the theoretical standing, as it is correctly signed (negative), statistically significant and its absolute magnitude being between 1 and 0 for real GDP, health infrastructure and access to sanitation. It shows that the model has self-adjusting mechanism for correcting short-run dynamics in the series to their long-run path. With the ECM (-1) for the variables (Real GDP, health infrastructure and access to sanitation) satisfying the rule of thumb, we can conclude that there exists a long run converging relationship between economic globalization and public health outcomes. The ECM $(-1)$ reveals that about 52.7 percent, 2 percent and zero percent of short-run disturbances are adjusted back to equilibrium path in the long-run. Additionally, the speed of error correction tends to be moderate for real GDP, the statistical significance at about 10 percent significance level and magnitude of 52.7 percent indicates that a deviation in health outcomes from equilibrium is corrected by 52.7 percent in the successive period.

\subsection{Impulse Response Function and Variance Decomposition Results}

\subsubsection{Impulse Response Function (IRFs)}

The Choleski decomposition traces the long-run responses of the system variables to one standard deviation shocks to the system innovations spanning the initial 10 quarters. The results showed that an increase in real GDP, health infrastructure shocks to health outcome depressed health outcome in the long-run, whereas the responses of health outcome to economic globalization, foreign aid, access to sanitation and government health expenditure shocks increase health outcomes, particularly in the short-run. The IRFs are attached as appendix. 


\subsubsection{Variance Decomposition Results (VDC)}

The forecast error variance decomposition tells us the proportion of the movements in a sequence due to its "own" shocks (health outcomes) versus the shocks to other variables (economic globalization and other variables). The impulse analysis and variance decompositions together called (innovation accounting) can be useful tools to examine the relationship among economic variables. It displays information on the role played by different structural shocks in explaining the variability of the series at different horizons. This gives a better explanation of the relationship which exists among the major variables in the study.
Table 10 presents the variances decomposition of population health outcome to innovation stocks in economic globalization. The "S.E", comprises the prediction noise of the variables at a given prediction period. The basis of this prediction noise is the difference between the actual and prediction values of the innovations to each of the endogenous variables in the VECM. The other columns show each variable as measured health outcome and economic globalization as well as the percentage of the prediction variance due to each innovation, with each row summing up to 100 .

Table 10: Variance Decomposition Analysis of Economic Globalization and Health Outcome (Infant Mortality)

\begin{tabular}{|l|l|l|l|l|l|l|l|l|}
\hline PERIOD & S.E & INFMOR & KOFIN & REALGDP & HELINFR & ODA & POPR & SANITA \\
\hline 1 & 0.001175 & 100.0000 & 0.000000 & 0.00000 & 0.000000 & 0.000000 & 0.000000 & 0.000000 \\
\hline 2 & 0.002588 & 97.35759 & 0.074042 & 0.386661 & 0.089147 & 0.265574 & 0.00614 & 0.072293 \\
\hline 3 & 0.004241 & 93.47529 & 0.125199 & 1.065283 & 0.102084 & 0.756575 & 0.004033 & 0.054619 \\
\hline 4 & 0.006072 & 88.44631 & 0.633390 & 1.904380 & 0.098478 & 1.411748 & 0.022742 & 0.032215 \\
\hline 5 & 0.008097 & 82.52624 & 1.476705 & 2.820016 & 0.116742 & 2.352035 & 0.138200 & 0.018128 \\
\hline 6 & 0.010362 & 75.94953 & 2.354951 & 3.777889 & 0.160014 & 3.705508 & 0.430588 & 0.019032 \\
\hline 7 & 0.012879 & 69.00607 & 3.176065 & 4.846686 & 0.219871 & 5.391522 & 0.9486130 & 0.054162 \\
\hline 8 & 0.015664 & 61.90279 & 3.900790 & 6.137055 & 0.286617 & 7.241540 & 1.675172 & 0.143785 \\
\hline 9 & 0.018724 & 54.85297 & 4.503887 & 7.637590 & 0.344006 & 9.113417 & 2.533885 & 0.295813 \\
\hline 10 & 0.022043 & 48.14919 & 4.962834 & 9.193972 & 0.378270 & 10.90549 & 3.420313 & 0.501842 \\
\hline
\end{tabular}

Note: The others are attached as an appendix.

Source: Authors' Computation using EVIEW 10.0

Table 10 shows that shocks to infant mortality is explained by a 100 percent shock to itself in the period at which it continuous to decline through to the 10 period. This can be attributed to series of factors including poor health facility, inadequate access to healthcare services following catastrophic health expenditure and the associated out-of-pockets (OOPs). The variability of health outcome to shocks in economic globalization (KOFIND) is unnoticeable in the first quarter, but begins to rise after the third period, and rises slowly till the tenth period. Thus the changes occurring in health outcome is not highly influenced by index of economic globalization as changes in economic globalization did not initially contribute much to the changes in health outcome, but its contribution became significant at the latter part. The variance of health outcome to the changes in real GDP and health infrastructure is relatively insignificant in the first period. Meanwhile, the changes start increasing from the $3^{\text {rd }}$ period down to the $10^{\text {th }}$ period over and above that of health infrastructure. The variations in real GDP seems to be the second major shocks to health outcome. The percentage variance of overseas development assistance(ODA) was initially zero but continues to rise from the $4^{\text {th }}$ period to the $10^{\text {th }}$ period, thus accounting for the majority of the shock to health outcome. From the table, the variance of population growth is zero from the period to the $7^{\text {th }}$ period, but relatively significant changes started from the $7^{\text {th }}$ period to the $10^{\text {th }}$ period. Finally, access to sanitation shock to health outcome is relatively zero and insignificant throughout the period. Therefore, aside the shock of health outcome to itself, the index of economic globalization, real GDP and foreign aid accounted for most of the variation in health outcome in Nigeria within the reviewing period.

\subsubsection{Sensitivity Analysis}

The final stage of the examination was the post estimation tests. This ensures the stability of the long-run coefficients by using the Inverse Roots of AR characteristic polynomial in the context of VECM. From the figure (see appendix), all the dots are inside the circle on inverse roots graph which implies that the VECM estimation is dynamically stable, robust enough to aid policy inference.

\section{POLICY IMPLICATION AND CONCLUSION}

\subsection{Policy Implication}

Some notable policy implications can be drawn from the empirical results:

- The paper points clearly to the significant role of other policy intervention, in particular health policy in other to reduce health outcome challenges in Nigeria and other developing countries.

- The empirical results from the normalized cointegrating coefficients shows negative relationship between health infrastructure and health outcome (infant mortality), 
negative relationship between foreign aid and health outcome, negative relationship between

population growth, access to sanitation and health outcome. In order to reduce these negative results, there is need to ensure universal access to cost-effective interventions, and to improve services essential to health, such as water and sanitation, environmental protection, and effective nutrition and health safety net programmes. Again, in order to reduce the negative effect of foreign aid, there is need to protect healthrelated spending from reduction in public expenditure against laid down standard $(15 \%$ of total expenditure) and foreign donors increasing and improving policy design to check the usage and allocation of foreign aid to the health.

- From the variance decomposition and impulse response results, outside its own shock, economic globalization, Real GDP and foreign aid variance accounted for more of the variations in health outcomes. This implies that for Nigeria to enjoy the benefits of globalization, she needs to manage the process of integration with the international economy in ways that maximize the economic opportunities and minimize the economic risk and social costs. In addition, macroeconomic and structural policies that accompany economic opening must be well designed and implemented.

- It is important to monitor the effects of globalization and health, and to ensure that the results of such monitoring are fed effectively into decisionmaking processes at the national and international level.

\subsection{Conclusion}

The objective of this paper was to examine how economic globalization affect health outcome in Nigeria. Specifically, it shows the channels of real GDP, health infrastructure, foreign aid, population growth, access to sanitation and government health expenditure as proximate determinants of health outcome in Nigeria. The paper is remarkably significant because it bridges the seemingly gap in the current knowledge about the effects of economic globalization on health outcomes. The coefficients of health infrastructure showed negative relationship with health outcome as expected theoretically. The coefficients of foreign assistance (aid) was negative against the theoretical postulation while population growth has a negative relationship with health outcome as theoretical expected. Furthermore, access to sanitation appeared negative against the expectations and government expenditure appeared negative as expected. The estimated results show that economic globalization account for about $-5 \%$ of the total shocks causing variation in health outcome. Real GDP account for about $-9 \%$ of the total shocks causing variation in health outcome while foreign aid account for about $10 \%$ variation in health outcome. To that end, the analysis shows that relying on trade liberalization and international financial flow to reduce health outcome may not generate the desired level of health system improvement in Nigeria. This needs to be complimented by designed and implemented health policy measures.

The paper, therefore, concludes that globalization may not have address health outcomes in Nigeria as it somehow challenged by extant factors including micro and macro issues. Therefore, a genuinely health-centered process of globalization can be achieved only by ensuring that the interest of developing countries, Nigeria inclusive and vulnerable populations are fully represented in global decision-making processes.

Data Availability: See the appendix

Conflict of Interest: This research or any of its parts has not been presented to any other Journal for whatsoever reason or publication

Funding Statement: The authors are solely responsible for the funding of the research and have not received any grant or funding scholarship for the publication of the research.

Acknowledgements: The authors acknowledged colleagues at Departments of Economics at both Enugu State University of Science and Technology, Enugu, Enugu State, Nigeria and Nnamdi Azikiwe University, Awka, Anambra, Nigeria.

\section{REFERENCES}

[1] A.T. Kearney/Foreign Policy Magazine (2002). Globalization Index, http://www.foreignpolicy.com

[2] Anand, S. and Barnighausen, T. (2004). Human resources and health outcomes: Cross-country econometric study. The Lancet 5, 364 (9445): 1603-9. 
[3] Anthony, I.W., Isaac, D.E. and Victor, A.K. (2019). Survival Analysis of under-five mortality and its Associated Determinants in Nigeria: Evidence from a survey Data. International Journal of Statistics and Application, 9(2): 59-66.

[4] Anthony, I.W., Isaac, D.E., and Victor, A.K. (2019). Survival analysis of under-five mortality and its associated determinants in Nigeria: Evidence form a survey data. International Journal of Statistics and Application 9(2): 59-66.

[5] Anyanwu, J.C. (2006). Does globalization affect economic growth in Africa? Globalization affect economic growth in Africa? Global Development studies 4(1-2): 54-90.

[6] Anyanwu, J.C. and Erhijakpor, A.E.O. (2007). Health expenditure and health outcomes in Africa. African Development Bank Economic Research Working Paper Series. No. 91

[7] Bergh, A. and Nilson, T. (2010). Do liberalization and globalization increase income inequality? European journal of Political Economy 26: 488-505.

[8] Bettcher, D. (1998). Globalization and Public Health. A new challenge for WHO. World Health, Number 2.

[9] Bettcher, D. and Yach, D. (1998). The globalization of public health ethics? Journal of International studies 27(3): 469-496.

[10] Bouzid, M., Oliver, C., and Paul, R.H. (2018). What is the impact of water sanitation and hygiene in healthcare facilities on care seeking behavior and patient satisfaction? A systematic review of the evidence from low-income and middle-income countries. BMJ Global Health, 1-14.

[11] Claeson, M. et al. (2000). Health, nutrition and population. In: Poverty reduction strategy paper Source book, World-Bank, Editor. 2000, The World Bank: Washington DC. http://www.worldbank.org/poverty/health/library/screbk.htm.

[12] Drecher, A., Gaston, N., and Martens, P. (2008). Measuring GlobalizationGauging its consequences. Springer, New York.

[13] Enders, W. (2010). Applied Econometric Time Series. John Wiley \& Sons Publications.

[14] Farzzanegan, M.R., and Hassan, M., (2017). The Impact of economic globalization on the Shadow economy in Egypt. CESIFO Working Paper Series 6424, CESIFO Group Munich.

[15] Fatile, J.O. and Adesanya, T.O. (2016). Globalization and health care service delivery in Lagos state University Teaching Hospital (LASUTH). Social Science and Law Journal of Policy Review and Development Studies. 5(1): 1-31.

[16] Fayissa, B, and Gutema, P. (2008). A health production function for SubSaharan Africa. Department of Economics and Finance working paper series, August, Middle Tennessee State University.

[17] Grossman, M. (1972). On the Concept of Health Capital and the Demand for Health Journal of Political Economy.

[18] Grossman, M. (1972). The demand for health: A Theoretical and Empirical Investigation. New York: NBER.

[19] Guobadia, D. (2019). African Continental Free Trade Area (AFCFTA) Treaty. A paper delivered at Lagos Business School, August.

[20] Health Policy Institute (2007). A new approach to reduce infant mortality and achieve equity.

[21] Herzer, D., Korbinian, N. and Peter, N. (2015). How does FDI affect health? Helmut Schmidt University, Department of Economics, Holstenhofweg $85 \quad 22043$ Hamburg, Germany. http://investmentpolicyhub.unctad.org/DPM.

[22] Holi, K.K. and Majumder, R. (2013). Health infrastructure, health outcome and economic wellbeing. A district level study in India. MPRA, Munich Personal RePEC Achieve. https://mpra.ub.uni-muenchen.de/53363)

[23] Hudak, K.M. (2014). Differential Health outcomes and trade: Does openness to trade affect childhood underweight and overweight?

[24] Huh, H-S, H. and Cyn-Y.P. (2019). A new index of globalization: Measuring impacts of integration on economic growth and income inequality. ADB Economics working paper series No. 587.

[25] Imo, C.K., Isugu-Abanihe, U.C. and Chikezie, D.C. (2017). Socioeconomic determinants of under-five children health outcome among childbearing mothers in Abia State, Nigeria, IJSA, 9(2): 17-27.

[26] Isai, M.C. (2007). Does globalization affect human well-being? Some Social Indicator Review 81(1): 103-126.
[27] Iyoha, M.A. (2004). Applied Econometrics Second Edition. Mindex Publishing, Nigeria: Benin City.

[28] Joseph, D. (2018). Infant mortality and public health expenditure in Nigeria: Empirical Explanation of the Nexus. Timisoara Journal of Economics and Business. 11(2): 149-164.

[29] Krabbe, P. (2016). The Measurement of Health and Health Status, 1st Edition. Academic Press.

[30] Lakshni, S.T. and Sahooa, D. (2013). Health infrastructure and health indicators: The case of Andhra Pradesh, India IOSR Journal of Humanities and Social Science (IOSR-JNSS), 6(6): 22-29.

[31] Levine, D.I. and Rothman, D. (2006). Does trade affect child health? Journal of Health Economic, 25: 38-554.

[32] Lipson, J., Anderson, L., and Bolton, S. (2010). The public health benefits of sanitation interventions EPAR Brief No. 104, Evans School of Public Affairs.

[33] Marguean, S. (2015). Economic Globalization: from microeconomics foundation of National determinants. Procedia Economics and Finance 27: 731-735. Elsevier.

[34] Martens, P. (2012). Maastricht Globalization index

[35] Martens, P. and Zywitz, D. (2006). Rethinking globalization: A modified globalization index, Journal of International Development. 18: 331-350

[36] Medic West Africa (2019). 2019 Healthcare Market Insights: Nigeria.

[37] Mohanty, S. (2017). Growth effects of economic globalization: A crosscountry analysis. The Institute for Social and Economic Change, Bangalore, Working Paper 381

[38] Mosley, W. and Chen, L. (1984). An analytical framework for the study of child survival in developing countries. Population and Development Review, 10: 25-45.

[39] Murkerjee, N., and Kreckhaus, J. (2011). Globalization and human wellbeing. International Political Science Review 33(2): 150-170.

[40] NBS (2018). Nigeria, Multiple, Indicator Cluster Survey 2016-2017 Final Report.

[41] Novgrion, J. and Atakorah, Y.B. (2016). How dos the health sector benefits from trade openness? Evidence from panel data across Sub-Saharan Africa Countries. MPRA (Munich personal RePEC Archive), 1-21, https://mpra.ub.uni-muenchen.de/72258/

[42] OECD (2010). Measuring globalization: OECD Economic globalization indicators, 2nd Edition. OECD Publication.

[43] Olper, A., Curzi, D., and Swinnen, J.F.M. (2017). Trade liberalization and child mortality: A synthetic control method, LICOS Discussion paper, No 387, Katholieke University Leuven, Licos Centre for Institutions and Economic Performance, Leuven.

[44] Owen, A.L. and Wu, S. (2002). Is trade good for your health? Review of International Economics, 15(4): 660-682.

[45] Owoseye, A. (2017). Nigeria has the highest infant mortality rate in the world-WHO. Retrieved from https://www.premiumtimesng.com/news/headlines/246720-nigeria-thirdhighest-infant-mortality-rate-world.html.

[46] Owoseye, A. (2017). Nigeria has third highest infant mortality rate in the world-WHO

[47] Peterson Institute for International Economics (2018). What is globalization? And how has the global economy shaped the United States.

[48] Popoola, O.T. (2018). Impact of economic globalization on life expectancy in Nigeria. Health Economics and Outcome Research 4(-2): 1-4.

[49] Randolph, J. (2001). G-index: Globalization measured, World Market Research Centre, www.globalinsight.com

[50] Riman, H.B. and Akpan, E.S. (2015). Health care financing and health outcomes in Nigeria: A state level study using multivariate Analysis. International Journal of Humanities and Social Sciences 2(15): 296-309.

[51] Sansoni, J. (2016). Health outcomes: An overview from an Australian Perspective. Australian Health Outcomes Collaborations, Australian Health Services Research Institute, University of Wollongong.

[52] Song, W.J., Kang, D.R., Yi, J.J., and Nam, C.M. (2017). Globalization and social determinant of health.

[53] Steven, P., Urbach, J. and Wills, G. (2013). Health Trade: The relationship between trade and health. Foreign Trade Review, 48(1): 125-135.

[54] UN Report (2019). Levels and trends in child mortality Estimates developed by the UN Inter-Agency Group for Child mortality estimation. 
[55] UNCTAD (2019). Trade and Development Report: United Nations Conference on trade and development.

[56] UNICEF (2014). Levels and trends in child mortality report 2014. Estimates developed by the UN Inter-Agency Group for child mortality estimation.

[57] Wagstaff, A. (2000). Research on Equity, Poverty and Health Outcomes. Lessons for the Development World. Health, Nutrition and Population (HNP) Discussion Paper. The World Bank, Washington, DC.

[58] Wako, H.A. (2018). Economic globalization, institution and health outcome. Unu-meru, Netherland.

[59] Welander, A., Lyttkens, C.H., and Nilsson, T. (2014). Globalization and Child health in developing countries: The role of democracy. Research institute of Industrial Economics, IFN working Paper No. 1016.

[60] Wolfgang, Y.T., Veronique, M., Bernard, Y.O., Arsene, S.M. and Valintin, H.P. (2013). Effects of poor sanitation on public health: case of Yopougon town (Abidjan), African Journal of Environmental Science and Technology 7(3): 87-92.
[61] Woodwaw, D., Drager, N., Beaglehole, R., and Lipson, R. (2001). Globalization and Health: A framework for analysis and action. Bulletin of the World Health Organization 79: 875-881.

[62] Zeynep, O. (2000). Determinants of health outcomes in industrialized countries: A Pooled, cross-country, time series analysis. OECD Economic Studies No 30.

\section{AUTHORS}

First Author - Nicholas Attamah, Ph.D., Department of Economics, Enugu State University of Science and Technology, Enugu, email: numanick@esut.edu.ng

Second Author - Chris U. Kalu, Ph.D., Department of Economics, Nnamdi Azikiwe University, Awka., E-mail: cu.kalu@unizik.edu.ng

\section{Appendix: Data Estimation Results}

\begin{tabular}{|c|c|c|c|c|c|c|c|}
\hline \multicolumn{8}{|c|}{$\begin{array}{l}\text { Date: } 12 / 02 / 19 \text { Time: } 08: 18 \\
\text { Sample: } 19702018\end{array}$} \\
\hline & INFMOR & KOFIND & REALGDP & HELINFR & $O D A$ & POPR & SANITA \\
\hline Mean & 113.8755 & 42.60180 & 393607.3 & 1.375804 & 0.859115 & 2.607276 & $443377 E$ \\
\hline Median & 123.9000 & 48.03922 & 275450.6 & $0.7<2040$ & 0.514087 & 2582376 & 44.80000 \\
\hline Maximum & 168.9000 & 58.44728 & 1239342 & 6370300 & 8.117241 & 3.048043 & 71.36667 \\
\hline Minimum & 62.76667 & 15.20503 & 4219,000 & 0.342000 & 0.054814 & 2.293336 & 15.33000 \\
\hline Std. Dev. & 26.92365 & 13.32031 & 351180.7 & 1.452929 & 1.416228 & 0.151628 & 16.93553 \\
\hline Skewness & -0.217807 & .0 .552292 & 0.915721 & 2.005993 & 4.126110 & 0.993633 & $=0.064576$ \\
\hline Kurtosis & 2.406774 & 1.893879 & 2.788518 & $6.244 \leq 59$ & 19.99145 & 4.677000 & 1.773515 \\
\hline Jarque-Bera & 1.105925 & 4.989033 & 6.939426 & 54.48320 & 728.4842 & 13.80485 & 3.105263 \\
\hline Probability & 0.575243 & 0.082536 & 0.031126 & 0,000000 & 0.000000 & 0.001005 & 0.211690 \\
\hline Sum & 5579,900 & $2087 \quad 488$ & 19286759 & $674: 440$ & 42.09665 & 127.7565 & 2172.550 \\
\hline Sum Sq. Dev. & 34794.38 & 8516.674 & $5.92 E+12$ & $101328:$ & 96.27341 & 1.103568 & 13766.98 \\
\hline Observations & 49 & 49 & 49 & 49 & 49 & 49 & 49 \\
\hline
\end{tabular}

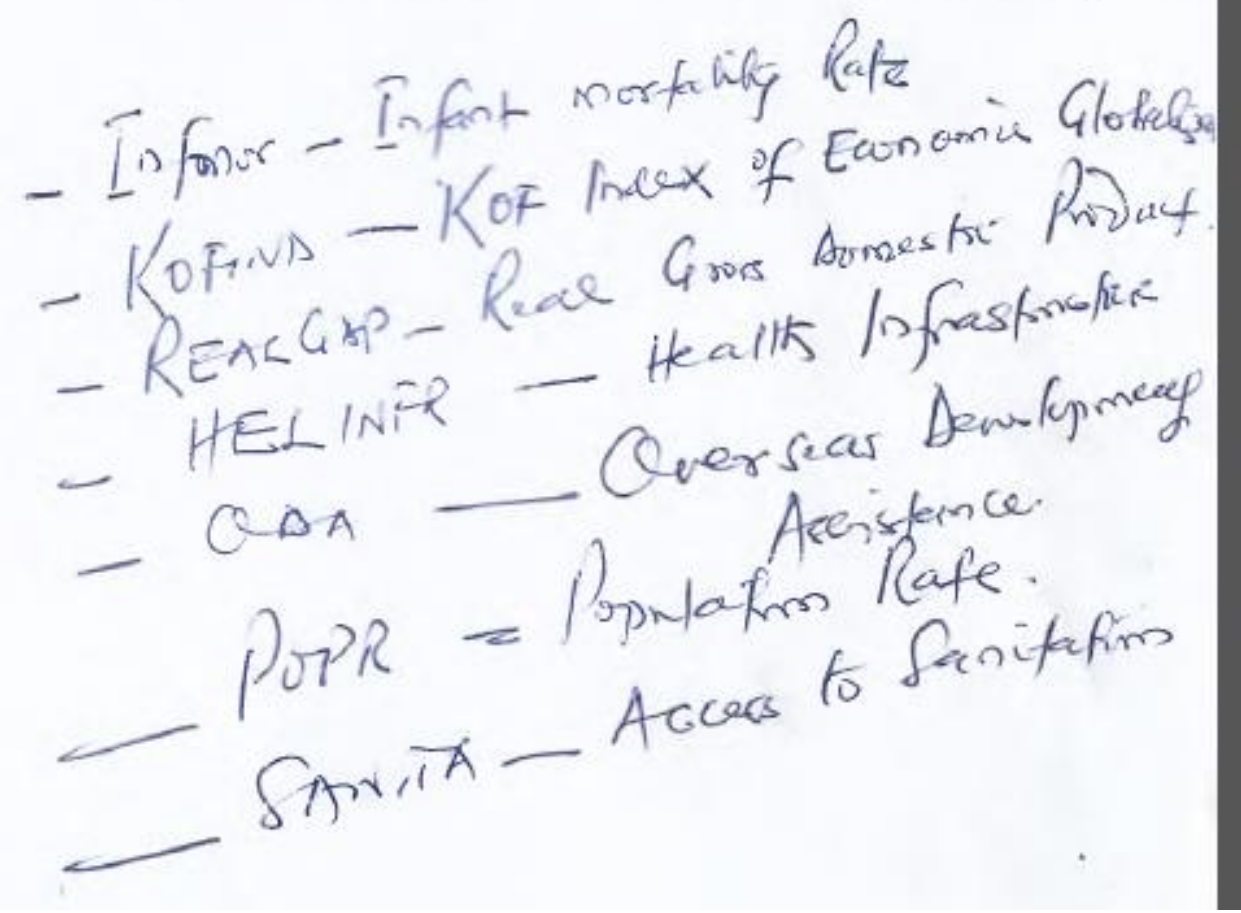

This publication is licensed under Creative Commons Attribution CC BY. 
Correlation

\begin{tabular}{|crrrrrrr|}
\hline & LKOFIND & LREALGDP & LHELINFR & LODA & LPOPR & \multicolumn{1}{c}{ LSANITA } & LGOVHEXP \\
\hline \hline LKOFIND & 1.000000 & 0.859463 & -0.197856 & 0.460346 & 0.092506 & 0.918996 & 0.890422 \\
LREALGDP & 0.859463 & 1.000000 & -0.057326 & 0.267440 & 0.062926 & 0.961713 & 0.894780 \\
LHELINFR & -0.197856 & -0.057326 & 1.000000 & -0.225543 & -0.115671 & -0.242712 & -0.441251 \\
LODA & 0.460346 & 0.267440 & -0.225543 & 1.000000 & -0.507233 & 0.379027 & 0.402191 \\
LPOPR & 0.092506 & 0.062926 & -0.115671 & -0.507233 & 1.000000 & 0.018816 & 0.030004 \\
LSANITA & 0.918996 & 0.961713 & -0.242712 & 0.379027 & 0.018816 & 1.000000 & 0.974005 \\
LGOVHEXP & 0.890422 & 0.894780 & -0.441251 & 0.402191 & 0.030004 & 0.974005 & 1.000000 \\
\hline
\end{tabular}




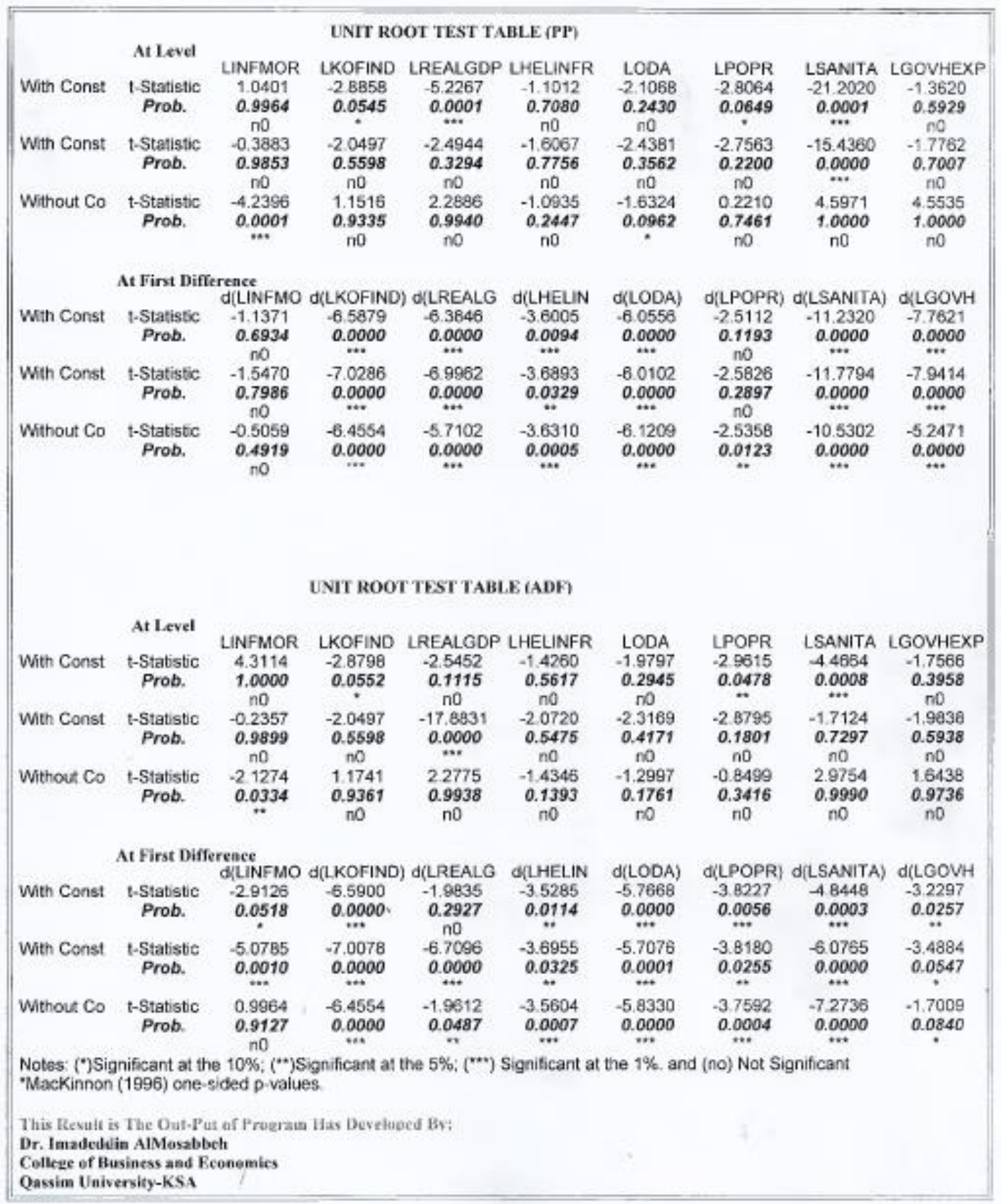

This publication is licensed under Creative Commons Attribution CC BY. 


\begin{tabular}{|c|c|c|c|c|c|c|c|}
\hline \multicolumn{6}{|c|}{$\begin{array}{l}\text { Date: } 12102 / 19 \text { Time: } 08: 12 \\
\text { Sample (adjusted): } 19732018 \\
\text { Included cbservations: } 46 \text { after adjustments } \\
\text { Trend assumption: Linear deterministic trend } \\
\text { Series: UNFMOR LKOFIND LREALGDP LHELINFR LODA LPOPR LSANITA LGOVHEXP } \\
\text { Lags interval (in first differences): } 1 \text { to } 2\end{array}$} & \\
\hline \multicolumn{6}{|c|}{ Unrestricted Cointegration Rank Test (Trace) } & & \\
\hline $\begin{array}{l}\text { Hypothesized } \\
\text { No. of CE(s) }\end{array}$ & Eigenvalue & $\begin{array}{l}\text { Trace } \\
\text { Statistic }\end{array}$ & $\begin{array}{c}0.05 \\
\text { Critical Value }\end{array}$ & Prob: $=$ & & & \\
\hline 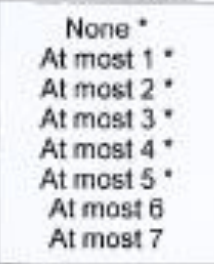 & $\begin{array}{l}0.906261 \\
0.848748 \\
0.799641 \\
0.672147 \\
0.585119 \\
0.428302 \\
0.211477 \\
0.005196\end{array}$ & $\begin{array}{l}398.3874 \\
289.4943 \\
202.6092 \\
128.6574 \\
77.35874 \\
36.88957 \\
11.16896 \\
0.239633\end{array}$ & $\begin{array}{l}159.5297 \\
125.6154 \\
95.75366 \\
69.81889 \\
47.85613 \\
29.79707 \\
15.49471 \\
3.841466\end{array}$ & $\begin{array}{l}0.0000 \\
0.0000 \\
0.0000 \\
0.0000 \\
0.0000 \\
0.0064 \\
0.2013 \\
0.6245\end{array}$ & & & \\
\hline \multicolumn{8}{|c|}{$\begin{array}{l}\text { Trace test indicates } 6 \text { cointegrating eqn(s) at the } 0.05 \text { level } \\
\text { "denotes rejection of the hypothesis at the } 0.05 \text { level } \\
\text { "MacKinnon-Haug-Michelis (1999) p-values }\end{array}$} \\
\hline \multicolumn{8}{|c|}{ Unrestricted Cointegration Rank Test (Maximum Eigenvalue) } \\
\hline $\begin{array}{l}\text { Hypothesized } \\
\text { No. of CE(s) }\end{array}$ & Eigenvalue & $\begin{array}{l}\text { Max-Eigen } \\
\text { Statistic }\end{array}$ & $\begin{array}{c}0.05 \\
\text { Critical Value }\end{array}$ & Prob."* & & & \\
\hline 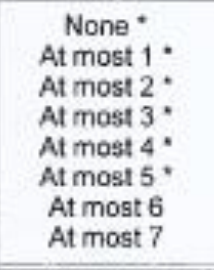 & $\begin{array}{l}0.906261 \\
0.848748 \\
0.799841 \\
0.672147 \\
0.585119 \\
0.428302 \\
0.211477 \\
0.005196 \\
\end{array}$ & $\begin{array}{l}108.8931 \\
86.88516 \\
73.95176 \\
51.29867 \\
40.46916 \\
25.72062 \\
10.92932 \\
0.239633 \\
\end{array}$ & $\begin{array}{l}52.36261 \\
46.23142 \\
40.07757 \\
33.87687 \\
27.58434 \\
21.13162 \\
14.26460 \\
3.841466 \\
\end{array}$ & $\begin{array}{l}0.0000 \\
0.0000 \\
0.0000 \\
0.0002 \\
0.0007 \\
0.0105 \\
0.1578 \\
0.6245 \\
\end{array}$ & & & \\
\hline \multicolumn{8}{|c|}{$\begin{array}{l}\text { Max-eigenvalue test indicates } 6 \text { cointegrating eqn(s) at the } 0.05 \text { level } \\
\text { denotes rejection of the hypothesis at the } 0.05 \text { level } \\
\text { "MacKinnon-Haug-Michelis (1999) p-values }\end{array}$} \\
\hline \multicolumn{8}{|c|}{ Unrestricted Cointegrating Coefficients (nommalized by b's11*b=1): } \\
\hline $\begin{array}{r}\text { LINFMAOR } \\
5.540145 \\
21.63459 \\
11.45292 \\
-36.47635 \\
6.515940 \\
-4.968240 \\
-4.550244 \\
21.00535\end{array}$ & $\begin{array}{l}\text { LKOFIND } \\
8.148795 \\
-33.38154 \\
-5.453003 \\
41.27773 \\
-6.092849 \\
-0.333945 \\
9.220621 \\
1.036431\end{array}$ & $\begin{array}{c}\text { LREALGDP } \\
10.91818 \\
-4.317897 \\
0.719826 \\
8.109430 \\
-3.815496 \\
-0.339082 \\
-2.618868 \\
-1.139553\end{array}$ & $\begin{array}{r}\text { LHELINFR } \\
-0.633696 \\
-5.190015 \\
-6.370140 \\
0.448625 \\
-4.408991 \\
0.403114 \\
2.751772 \\
-0.548725 \\
\end{array}$ & $\begin{array}{c}\text { LODA } \\
-0.978304 \\
0.746349 \\
-2.313295 \\
0.461402 \\
-1.041292 \\
-0.989706 \\
-1.222773 \\
-0.716593 \\
\end{array}$ & $\begin{array}{c}\text { LPOPR } \\
-48.83992 \\
-5.728287 \\
19.30928 \\
-103.6036 \\
-16.91420 \\
-49.88440 \\
22.13487 \\
31.30671 \\
\end{array}$ & $\begin{array}{l}\text { LSANITA } \\
-4.602568 \\
-30.88283 \\
45.53704 \\
-74.27150 \\
71.18570 \\
-19.67347 \\
-0.957379 \\
31.52035 \\
\end{array}$ & $\begin{array}{c}\text { LGOVHEXP } \\
-0.297156 \\
6.291197 \\
-4.784615 \\
-4.193385 \\
-5.411480 \\
-2.229343 \\
4.803065 \\
1.968228\end{array}$ \\
\hline \multicolumn{6}{|c|}{ Unrestricted Adjustment Coefficients (alpha): } & & \\
\hline $\begin{array}{l}\text { D(LINFMOR) } \\
\text { D(LKOFIND) } \\
\text { D(LREALGDP) } \\
\text { D(LHELINFR) }\end{array}$ & $\begin{array}{r}0.000100 \\
0.021444 \\
-0.095112 \\
-0.0030: 7\end{array}$ & $\begin{array}{r}-0.000520 \\
0.014348 \\
-0.036415 \\
0.045254\end{array}$ & $\begin{array}{r}0.000512 \\
-0.020270 \\
-0.032291 \\
0.081228\end{array}$ & $\begin{array}{l}-0.000242 \\
-0.039495 \\
-0.044725 \\
-0.012558\end{array}$ & $\begin{array}{r}-0.000520 \\
-0.016302 \\
0.035269 \\
-0.002087\end{array}$ & $\begin{array}{r}-6.01 E-05 \\
-0.020967 \\
-0.003859 \\
0.017429\end{array}$ & $\begin{array}{l}-0.000109 \\
-0.012619 \\
-0.003018 \\
-0.024722\end{array}$ \\
\hline
\end{tabular}


Johansen Cointegration Test

\begin{tabular}{|c|c|c|c|c|c|c|c|}
\hline $\begin{array}{c}\text { D(LODA) } \\
\text { D(LPOPR) } \\
\text { D(LSANITA) } \\
\text { D(LGOVHEXP) }\end{array}$ & $\begin{array}{r}0.140864 \\
0.000955 \\
-0.000137 \\
-0.041755\end{array}$ & $\begin{array}{r}-0.017382 \\
-0.000498 \\
0.000129 \\
-0.058031\end{array}$ & $\begin{array}{r}0.151063 \\
-0.001109 \\
-6.196-06 \\
0.018326\end{array}$ & $\begin{array}{r}-0.180211 \\
0.000218 \\
-1.65 E-05 \\
0.061128\end{array}$ & $\begin{array}{c}0.135735 \\
0.007081 \\
-0.000241 \\
0.075533\end{array}$ & $\begin{array}{r}0.106181 \\
0.000501 \\
0.000380 \\
-0.026091\end{array}$ & $\begin{array}{r}0.037865 \\
-0.000324 \\
-8.48 E-05 \\
-0.011425\end{array}$ \\
\hline \multicolumn{2}{|c|}{1 Cointegrating Equation(s): } & Log likelihood & 902.7539 & & & & \\
\hline \multicolumn{8}{|c|}{ Normalized cointegrating coefficients (standard error in parentheses) } \\
\hline LINFMOR & LKOFIND & LREALGDP & LHELINFR & LODA & LPOPR. & LSANITA & LGOVHEXP \\
\hline 1.000000 & $\begin{array}{l}1.470863 \\
(0.33085)\end{array}$ & $\begin{array}{l}1.970740 \\
(0.14562)\end{array}$ & $\begin{array}{l}-0.114383 \\
(0.09080)\end{array}$ & $\begin{array}{r}-0.176585 \\
(0.03533)\end{array}$ & $\begin{array}{l}-8.8 t \leq \leq 58) \\
(1.1+\leq t 0)\end{array}$ & $\begin{array}{r}-0.830767 \\
(1.05909)\end{array}$ & $\begin{array}{r}-0.053637 \\
\langle 0.12041\rangle\end{array}$ \\
\hline \multicolumn{8}{|c|}{ Adjustment coefficients (standard error in parentheses) } \\
\hline D(LINFMOR) & $\begin{array}{l}-0.000555 \\
(0.00121)\end{array}$ & & & & & & \\
\hline D(LKOFIND) & $\begin{array}{l}0.118803 \\
(0.07587)\end{array}$ & & & & & & \\
\hline D(LREALGDP) & $\begin{array}{r}-0.526935 \\
\langle 0.10312\rangle\end{array}$ & & & & & & \\
\hline D(LHELINFR) & $\begin{array}{r}-0.016882 \\
(0.13367)\end{array}$ & & & & & & \\
\hline D(LODA) & $\begin{array}{l}0.780405 \\
(0.47443)\end{array}$ & & & & & & \\
\hline$D(L P O P R)$ & $\begin{array}{l}0.005293 \\
(0.00245)\end{array}$ & & & & & & \\
\hline D(LSANITA) & $\begin{array}{l}-0.000757 \\
(0.00075)\end{array}$ & & & & & & \\
\hline $\mathrm{D}($ LGOVHEXP) & $\begin{array}{l}-0.231330 \\
(0.16549)\end{array}$ & & & & & & \\
\hline \multicolumn{2}{|c|}{2 Cointegrating Equation(s): } & Log likelihood & 946. 1965 & & & & \\
\hline \multicolumn{8}{|c|}{ Normalized cointegrating coefficients (standard error in parentheses) } \\
\hline LINFMOR & LKOFIND & LREALGDP & LHELINFR & LODA & LPOPR. & LSANITA & LGOVHEXP \\
\hline 1,000000 & 0.000000 & $\begin{array}{l}0.911542 \\
(0.06362)\end{array}$ & $\begin{array}{l}-0.175837 \\
(0.04839)\end{array}$ & $\begin{array}{r}-0.073588 \\
(0.01660)\end{array}$ & $\begin{array}{l}-434247 \\
10.5970)\end{array}$ & $\begin{array}{r}-1.12 \div 982 \\
(0.54978)\end{array}$ & $\begin{array}{l}0,114458 \\
(0.06333)\end{array}$ \\
\hline 0.000000 & 1.000000 & $\begin{array}{l}0.720120 \\
(0.04143)\end{array}$ & $\begin{array}{l}0.041645 \\
(0.03151)\end{array}$ & $\begin{array}{l}-0.070038 \\
(0.01081)\end{array}$ & $\begin{array}{l}-2 \operatorname{s37145} \\
(0.30915)\end{array}$ & $\begin{array}{l}0.197990 \\
1035797\rangle\end{array}$ & $\begin{array}{r}-0.114283 \\
(0.04123)\end{array}$ \\
\hline \multicolumn{8}{|c|}{ Adjustment coefficients (standard error in parentheses) } \\
\hline D(LINFMOR) & $\begin{array}{l}-0.011806 \\
(0.00438)\end{array}$ & $\begin{array}{l}0.016545 \\
(0.00674)\end{array}$ & & & & & \\
\hline D(LKOFIND) & $\begin{array}{l}0.429223 \\
(0.29976)\end{array}$ & $\begin{array}{l}-0.304225 \\
(0.46122)\end{array}$ & & & & & \\
\hline D(LREALGDP) & $\begin{array}{l}-1.314749 \\
(0.38623\rangle\end{array}$ & $\begin{array}{l}0.440525 \\
(0.59428)\end{array}$ & & & & & \\
\hline D(LHELINFR) & $\begin{array}{r}0.962165 \\
(0.50385)\end{array}$ & $\begin{array}{r}-1.535472 \\
(0.77525)\end{array}$ & & & & & \\
\hline$D(L O D A)$ & $\begin{array}{r}0.404361 \\
(1.91105)\end{array}$ & $\begin{array}{r}1.728093 \\
(2.94040)\end{array}$ & & & & & \\
\hline $\mathrm{D}(\mathrm{LPOPR})$ & $\begin{array}{l}-0.005488 \\
(0.00966)\end{array}$ & $\begin{array}{l}0.024421 \\
(0.01487)\end{array}$ & & & & & \\
\hline D(LSANITA) & $\begin{array}{r}0.002024 \\
(0.00286)\end{array}$ & $\begin{array}{l}-0.005405 \\
(0.00456)\end{array}$ & & & & & \\
\hline D(LGOVHEXP) & $\begin{array}{r}-1.486803 \\
(0.62050)\end{array}$ & $\begin{array}{r}1.596804 \\
(0.95472)\end{array}$ & & & & & \\
\hline \multicolumn{2}{|c|}{3 Cointegrating Equation(s): } & Log likelihood & 983.1724 & & & & \\
\hline \multicolumn{8}{|c|}{ Normalized cointegrating ccefficients (standard error in parentheses) } \\
\hline LNFMOR & LKOFIND & LREALGDP & LHELINFR & LODA & LPOPR & LSANSA & LGOVHEXP \\
\hline
\end{tabular}

This publication is licensed under Creative Commons Attribution CC BY. 
Johansen Cointegration Test

\begin{tabular}{|c|c|c|c|c|c|c|c|}
\hline 1.000000 & 0,000000 & 0.000000 & $\begin{array}{r}-0.825718 \\
(0.12085)\end{array}$ & $\begin{array}{r}-0.365077 \\
(0.04253)\end{array}$ & $\begin{array}{l}4.327582 \\
(1.21684)\end{array}$ & $\begin{array}{l}8.234962 \\
(1.26945)\end{array}$ & $\begin{array}{r}-0.942710 \\
(0+6197)\end{array}$ \\
\hline 0.000000 & 1.000000 & 0.000000 & $\begin{array}{l}-0.471921 \\
(0.10185)\end{array}$ & $\begin{array}{r}-0.300330 \\
(0.035 B 4)\end{array}$ & $\begin{array}{l}4.249170 \\
(1.0255 \vdots\end{array}$ & $\begin{array}{l}7.590000 \\
(1.06987)\end{array}$ & $\begin{array}{l}-0.949449 \\
(0.13651)\end{array}$ \\
\hline 0.000000 & 0.000000 & 1.000000 & $\begin{array}{r}0.713167 \\
(0.14871)\end{array}$ & $\begin{array}{l}0.319797 \\
(0.05233)\end{array}$ & $\begin{array}{l}-9.840481 \\
(149731)\end{array}$ & $\begin{array}{r}-10.26497 \\
(1.56205)\end{array}$ & $\begin{array}{l}1.159759 \\
(0.19931)\end{array}$ \\
\hline \multicolumn{8}{|c|}{ Adjustment coefficients (standard error in parentheses) } \\
\hline D(LINFMOR) & $\begin{array}{l}-0.005940 \\
(0.00428)\end{array}$ & $\begin{array}{l}0.013752 \\
(0.00593)\end{array}$ & $\begin{array}{l}0.001521 \\
(0.00201)\end{array}$ & F & & & \\
\hline D(LKOFIND) & 0.197074 & -0.193694 & 0.157585 & & & & \\
\hline & $(0.32287)$ & $(0.44757)$ & $(0.15132)$ & & & & \\
\hline D(LREALGDP) & -1.684570 & 0.616605 & -0.904461 & & & & \\
\hline & $(0.40614)$ & $(0.56300)$ & $(0.19035)$ & & & & \\
\hline D(LHELINFR) & $\begin{array}{l}1.892464 \\
(041497)\end{array}$ & $\begin{array}{r}-1.978409 \\
(0.57524)\end{array}$ & $\begin{array}{r}-0.170201 \\
(0.19449)\end{array}$ & & & & \\
\hline D(LODA) & 2.134467 & 0.904349 & 1.721765 & & & & \\
\hline & $(2.02465)$ & (2.80662) & $(0.94892)$ & & & & \\
\hline D(LPOPR) & -0.018192 & 0.030470 & 0.011785 & & & & \\
\hline D(LSANITA) & $\begin{array}{l}(0.00950) \\
0.001953\end{array}$ & $(0.01317)$ & $(0.00445)$ & & & & \\
\hline & $\begin{array}{l}0.001953 \\
(0.00333)\end{array}$ & $(0.00462)$ & $(0.00156)$ & & & & \\
\hline D(LGOVHEXP) & $\begin{array}{r}-1.276917 \\
(0.69190)\end{array}$ & $\begin{array}{l}1.496973 \\
(0.95913)\end{array}$ & $\begin{array}{l}-0.192128 \\
(0.32428)\end{array}$ & & & & \\
\hline 4 Cointegrating $\mathrm{E}$ & quation(s): & Log likelihood & 1008.822 & & & & \\
\hline \multicolumn{8}{|c|}{ Normalized cointegrating coefficients (standard error in parentheses) } \\
\hline LINFMOR & LKOFIND & LREALGDP & LHELLINFR & LODA & LPOPR & ISANITA & LGOVHEXP \\
\hline 1.000000 & 0.000000 & 0.000000 & 0.000000 & $\begin{array}{r}-0.207332 \\
0.025370\end{array}$ & $\begin{array}{l}6.464732 \\
(0.704=4)\end{array}$ & $\begin{array}{l}3.438887 \\
0.810407\end{array}$ & $\begin{array}{r}-0.488145 \\
(0.08290)\end{array}$ \\
\hline 0.000000 & 1.000000 & 0.000000 & 0,000000 & -0.210175 & 5.470eno & 7.708549 & -0689652 \\
\hline 0.000000 & 0.000000 & 1.000000 & 0.000000 & 0.183554 & $.11 .00 \mathrm{c} 30$ & -10.44110 & 0.767154 \\
\hline & & & & $(0.03415)$ & $(0.5+2 e \theta)$ & $(1.09108)$ & $\{0.11161\}$ \\
\hline 0.000000 & 0.000000 & 0.000000 & 1.000000 & $\begin{array}{l}0.191040 \\
(0.03758)\end{array}$ & $\begin{array}{l}2386232 \\
(1.04402)\end{array}$ & $\begin{array}{l}0.246968 \\
(1.20037)\end{array}$ & $\begin{array}{l}0.550510 \\
(0.12279)\end{array}$ \\
\hline \multicolumn{8}{|c|}{ Adjustment coefficients (standard error in parentheses) } \\
\hline D(LINFMOR) & $\begin{array}{l}0.002881 \\
(0.00727)\end{array}$ & $\begin{array}{l}0.003770 \\
(0.00887)\end{array}$ & $\begin{array}{r}-0.000440 \\
(0.00235)\end{array}$ & $\begin{array}{r}-0.000609 \\
(0.00136)\end{array}$ & & & \\
\hline D(LKOFIND) & $\begin{array}{l}1.601223 \\
(0.46977)\end{array}$ & $\begin{array}{r}-1.782870 \\
(0.57277)\end{array}$ & $\begin{array}{l}-0.154585 \\
\langle 0.15159\rangle\end{array}$ & $\begin{array}{r}0.023795 \\
(0.08757)\end{array}$ & & & \\
\hline D(LREALGDP) & -0.053152 & $-1,229557$ & -1.267159 & 0.434895 & & & \\
\hline D(LHELINFR) & $(0.81097)$ & $(0.74493)$ & $(0.19715)$ & $(0,11389)$ & & & \\
\hline D(LFELINFR) & $\begin{array}{r}2.350529 \\
(0.72449)\end{array}$ & $\begin{array}{l}-2.496769 \\
(0.88333)\end{array}$ & $\begin{array}{l}-0272038 \\
(023378)\end{array}$ & $\begin{array}{l}-0.756005 \\
(0.13505)\end{array}$ & & & \\
\hline $\mathrm{D}(\mathrm{LODA})$ & $\begin{array}{l}8.707892 \\
(323787)\end{array}$ & $\begin{array}{r}-6.534335 \\
(3.94776)\end{array}$ & $\begin{array}{r}0.260360 \\
(1.04481)\end{array}$ & $\begin{array}{r}-1.042191 \\
(0.60355)\end{array}$ & & & \\
\hline $\mathrm{D}(\mathrm{LPOPR})$ & -0.026129 & 0.039451 & 0.013549 & 0.009145 & & & · \\
\hline & $\{0.01666\rangle$ & $(0.02031)$ & $(0.00538)$ & $(0.00311)$ & & & \\
\hline D(LSANITA) & $\begin{array}{r}0.002566 \\
(0.00587)\end{array}$ & $\begin{array}{r}-0.006063 \\
(0.00716)\end{array}$ & $\begin{array}{r}0.002185 \\
(0.00190)\end{array}$ & $\begin{array}{l}-0.000549 \\
(0.00109)\end{array}$ & & . & \\
\hline D(LGOVHEXP) & $\begin{array}{r}-3.506650 \\
(1.10828)\end{array}$ & $\begin{array}{l}4.020206 \\
(1.35126)\end{array}$ & $\begin{array}{r}0.303587 \\
(0.35762)\end{array}$ & $\begin{array}{l}0.238326 \\
(0.20659)\end{array}$ & & & \\
\hline 5 Cointegrating $\mathrm{E}$ & quation(s): & Log likelihood & 1029.056 & & a & & \\
\hline \multicolumn{8}{|c|}{ Normalized cointegrating coefficients (standard error in parentheses) } \\
\hline LINFMOR & LKOFIND & LREALGDP & LHELINFR & LODA & LPOPR & LSANITA & LGOVHEXP \\
\hline 1.000000 & 0.000000 & 0.000000 & 0.000000 & 0.000000 & -14.89092 & 17.28592 & -0.878919 \\
\hline & & & & & (4.34438) & $(4.52140)$ & $(0.46643)$ \\
\hline
\end{tabular}

This publication is licensed under Creative Commons Attribution CC BY. 
Johansen Cointegration Test

\begin{tabular}{|c|c|c|c|c|c|c|c|}
\hline 0.000000 & 1.000000 & 0.000000 & 0.000000 & 0.000000 & $\begin{array}{r}-16.16771 \\
(435874)\end{array}$ & $\begin{array}{l}16.67488 \\
(4.53634)\end{array}$ & $\begin{array}{r}-1.085785 \\
(0.48204)\end{array}$ \\
\hline 0.000000 & 0.000000 & 1.000000 & 0.000000 & 0.000000 & $\begin{array}{l}7.211318 \\
(3.73426)\end{array}$ & $\begin{array}{r}-18.27350 \\
\text { (3.89642) }\end{array}$ & $\begin{array}{r}1.113112 \\
(0.41812)\end{array}$ \\
\hline 0.000000 & 0.000000 & 0.000000 & 1.000000 & 0.000000 & $\begin{array}{l}22.25652 \\
(3.90991)\end{array}$ & $\begin{array}{r}-7.904856 \\
(4.06819)\end{array}$ & $\begin{array}{l}0.910577 \\
(0.43767)\end{array}$ \\
\hline 0.000000 & 0.000000 & 0.000000 & 0.000000 & 1.000000 & $\begin{array}{r}-102.9540 \\
(21.5904)\end{array}$ & $\begin{array}{l}42.67085 \\
(22.4701)\end{array}$ & $\begin{array}{r}-1.884779 \\
(2.41742)\end{array}$ \\
\hline \multicolumn{8}{|c|}{ Adjustment coefficients (standard error in parentheses) } \\
\hline D(LINFMOR) & $\begin{array}{l}-0.000508 \\
(0.00589)\end{array}$ & $\begin{array}{l}0.006939 \\
(0.00715)\end{array}$ & $\begin{array}{r}0.001545 \\
(0.00195)\end{array}$ & $\begin{array}{r}0.001685 \\
(0.00123)\end{array}$ & $\begin{array}{l}0.001045 \\
(0.00038)\end{array}$ & & \\
\hline DYLKOFIND) & $\begin{array}{r}1.495003 \\
(0.45437)\end{array}$ & $\begin{array}{l}-1.683347 \\
(0.55157)\end{array}$ & $\begin{array}{r}-0.092387 \\
(0.15014)\end{array}$ & $\begin{array}{l}0.095683 \\
(0.09501)\end{array}$ & $\begin{array}{r}0.035833 \\
(0.02901)\end{array}$ & & \\
\hline D(LREALGDP) & $\begin{array}{r}0.176561 \\
(0.54073)\end{array}$ & $\begin{array}{c}-1.444448 \\
(0.65640)\end{array}$ & $\begin{array}{r}-1.401729 \\
(0.17868)\end{array}$ & $\begin{array}{r}0.279361 \\
(0.11306)\end{array}$ & $\begin{array}{c}0.083206 \\
(0.03452)\end{array}$ & & \\
\hline D(LHELINFR) & $\begin{array}{r}2.336933 \\
(0.73208)\end{array}$ & $\begin{array}{r}-2.494056 \\
(0.8 B 8 B B)\end{array}$ & $\begin{array}{r}-0.264077 \\
(0.24190)\end{array}$ & $\begin{array}{l}-0.748804 \\
(0.15307)\end{array}$ & $\begin{array}{l}-0.154770 \\
(0.04674)\end{array}$ & & \\
\hline$D(L O D A)$ & $\begin{array}{l}9.592656 \\
(3.06464)\end{array}$ & $\begin{array}{l}-7.361650 \\
(3.72020)\end{array}$ & $\begin{array}{l}-0.257726 \\
(1.01266)\end{array}$ & $\begin{array}{r}-1.640986 \\
(0.64079)\end{array}$ & $\begin{array}{r}-0.724773 \\
(0.19564)\end{array}$ & & \\
\hline D(LPOPR $)$ & $\begin{array}{r}-0.019084 \\
(0.01414)\end{array}$ & $\begin{array}{l}0.032853 \\
(0.01717)\end{array}$ & $\begin{array}{r}0.009424 \\
(0.00467)\end{array}$ & $\begin{array}{r}0.004376 \\
(0.00296)\end{array}$ & $\begin{array}{l}0.000234 \\
(0.00090)\end{array}$ & & \\
\hline D(LSANITA) & $\begin{array}{l}0.000985 \\
(0.00557)\end{array}$ & $\begin{array}{l}-0.004584 \\
(0.00577)\end{array}$ & $\begin{array}{r}-0.001265 \\
(0.00184)\end{array}$ & $\begin{array}{r}0.000515 \\
(0.00117)\end{array}$ & $\begin{array}{r}0.000487 \\
(0.00036)\end{array}$ & & \\
\hline D(LGOVHEXP) & $\begin{array}{l}-3.013700 \\
\{0.91950)\end{array}$ & $\begin{array}{r}3.559263 \\
(1.11619)\end{array}$ & $\begin{array}{r}0.014933 \\
(0.30383)\end{array}$ & $\begin{array}{r}-0.095296 \\
(0.19226)\end{array}$ & $\begin{array}{c}-0.095428 \\
(0.05870)\end{array}$ & & \\
\hline \multicolumn{2}{|c|}{6 Cointegrating Equation(s): } & Log likelihood & 1041.917 & & & & \\
\hline \multicolumn{8}{|c|}{ Normalized cointegrating coefficients (standard error in parentheses) } \\
\hline LINFMOR & LKOFIND & LREALGDP & LHELINFR & LODA & LPOPR & LSANITA & LGOVHEXP \\
\hline 1.000000 & 0.000000 & 0.000000 & 0.000000 & 0.000000 & 0.000000 & $\begin{array}{r}10.33519 \\
(1.77176)\end{array}$ & $\begin{array}{l}-0.327005 \\
\text { (0.2048D) }\end{array}$ \\
\hline 0.000000 & 1.000000 & 0.000000 & 0.000000 & 0.000000 & 0.000000 & $\begin{array}{l}9.123107 \\
(1.63617)\end{array}$ & $\begin{array}{l}-0.488145 \\
(0.18913)\end{array}$ \\
\hline 0.000000 & 0,000000 & 1.000000 & 0.000000 & 0.000000 & 0.000000 & $\begin{array}{r}-14.90517 \\
(2.36661)\end{array}$ & $\begin{array}{l}0.845354 \\
\left.(0.2735)^{\prime}\right)\end{array}$ \\
\hline 0.000000 & 0.000000 & 0.000000 & 1.000000 & 0.000000 & 0.000000 & 2.490942 & $\begin{array}{l}0.085112 \\
(0.20070)\end{array}$ \\
\hline 0.000000 & 0.000000 & 0000000 & 0.000000 & 1.000000 & 0.000000 & $\begin{array}{r}-5.417918 \\
(6.79627)\end{array}$ & $\begin{array}{r}1.933650 \\
(0.78558)\end{array}$ \\
\hline 0,000000 & 0.000000 & 0.000000 & 0.000000 & 0.000000 & 1.000000 & $\begin{array}{r}-0.467090 \\
(0.19030)\end{array}$ & $\begin{array}{l}0.037089 \\
(0.02200)\end{array}$ \\
\hline \multicolumn{8}{|c|}{ Adjustment coefficients (standard error in parentheseg) } \\
\hline D(LINFMOR) & $\begin{array}{l}-0.000210 \\
(0.00590)\end{array}$ & $\begin{array}{c}0.006959 \\
(0.00712)\end{array}$ & $\begin{array}{r}0.001565 \\
(0.00194)\end{array}$ & $\begin{array}{r}0.001661 \\
(0.00123)\end{array}$ & $\begin{array}{l}-0.000998 \\
(0.00040)\end{array}$ & $\begin{array}{l}0.054605 \\
(0.01673)\end{array}$ & \\
\hline D(KKOFIND) & $\begin{array}{l}1.599169 \\
(0.42091)\end{array}$ & $\begin{array}{r}-1.676345 \\
(0.50784)\end{array}$ & $\begin{array}{l}-0.085278 \\
(0.13827)\end{array}$ & $\begin{array}{l}0.087231 \\
(0.08755)\end{array}$ & $\begin{array}{l}0.056584 \\
(0.02826)\end{array}$ & $\begin{array}{r}3.788932 \\
(1.19339)\end{array}$ & \\
\hline D(LREALGDP) & $\begin{array}{l}0.194838 \\
(0.54317)\end{array}$ & $\begin{array}{r}-1.443226 \\
(0.65534)\end{array}$ & $\begin{array}{r}-1.400488 \\
(0.17843)\end{array}$ & $\begin{array}{r}0.277886 \\
(0.11298)\end{array}$ & $\begin{array}{r}0.086827 \\
(0.03647)\end{array}$ & $\begin{array}{r}8.449929 \\
(1.54002)\end{array}$ & . \\
\hline D(LHELINFR) & $\begin{array}{r}2.250342 \\
(0.72149)\end{array}$ & $\begin{array}{l}-2.489877 \\
(0.87049)\end{array}$ & $\begin{array}{r}-0.269987 \\
(0.23701)\end{array}$ & $\begin{array}{r}-0.739778 \\
(0.15007)\end{array}$ & $\begin{array}{l}-0.172019 \\
(0.04845)\end{array}$ & $\begin{array}{l}1,924965 \\
(2.04561)\end{array}$ & \\
\hline D(LODA) & 9.065124 & $\begin{array}{r}-7.397106 \\
(3.55696)\end{array}$ & $\begin{array}{l}-0.293730 \\
(0.96846)\end{array}$ & $\begin{array}{r}-1.598183 \\
(0.61323)\end{array}$ & $\begin{array}{r}-0.829861 \\
(0.19796)\end{array}$ & $\begin{array}{r}7.213853 \\
\text { (8.35865) }\end{array}$ & \\
\hline D(LPOPR) & $\begin{array}{l}-0.021574 \\
\langle 0.01357\rangle\end{array}$ & $\begin{array}{l}0.032696 \\
(0.01638)\end{array}$ & $\begin{array}{l}0.009254 \\
(0.00446)\end{array}$ & $\begin{array}{r}0.004579 \\
(0.00282)\end{array}$ & $\begin{array}{l}-0.000262 \\
(0.00091)\end{array}$ & $\begin{array}{r}-0.131065 \\
(0.03848)\end{array}$ & \\
\hline D(LSANITA $)$ & $\begin{array}{l}0.0009 \mathrm{C} 3 \\
(0.00450)\end{array}$ & $\begin{array}{r}-0.004710 \\
(0.00553)\end{array}$ & $\begin{array}{l}-0.001394 \\
(0.00151)\end{array}$ & $\begin{array}{r}0.000668 \\
(0.00095)\end{array}$ & $\begin{array}{l}0.000111 \\
(0.00031)\end{array}$ & $\begin{array}{r}-0.007345 \\
(0.01299)\end{array}$ & \\
\hline $\mathrm{D}($ LGOVHEXP $)$ & $\begin{array}{r}-2.894075 \\
(0.89811)\end{array}$ & $\begin{array}{r}3.567976 \\
(1.08359)\end{array}$ & $\begin{array}{l}0.023780 \\
(0.29503)\end{array}$ & $\begin{array}{r}-0.105813 \\
(0.18681)\end{array}$ & $\begin{array}{r}-0.069806 \\
(0.06031)\end{array}$ & $\begin{array}{l}-3.585642 \\
(2.54638)\end{array}$ & \\
\hline
\end{tabular}

This publication is licensed under Creative Commons Attribution CC BY. 
Johansen Cointegration Test

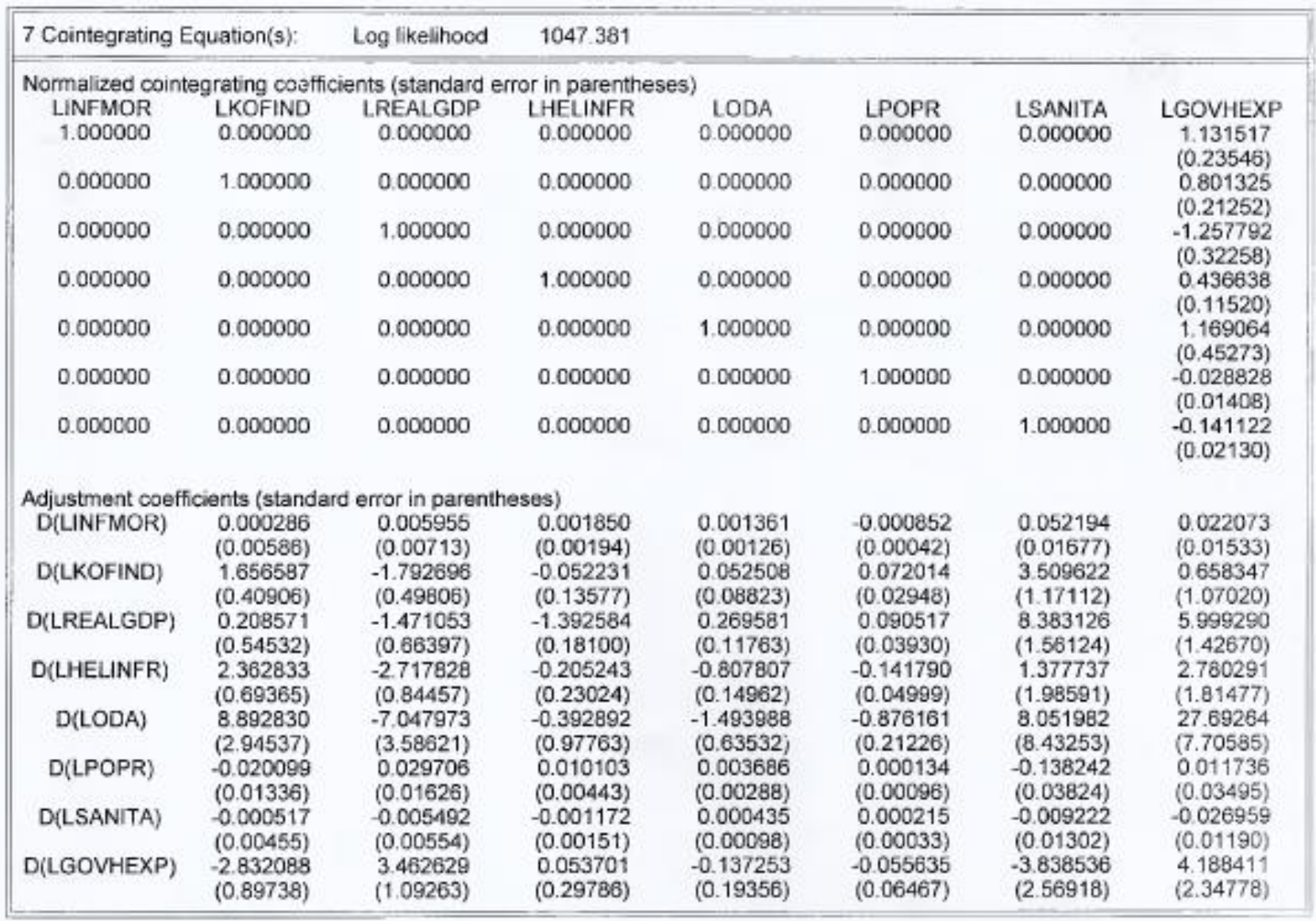




\begin{tabular}{|c|c|c|c|c|c|c|c|}
\hline \multicolumn{8}{|c|}{\begin{tabular}{||l} 
Vector Error Correction Estimates \\
Date: $12 / 02 / 19$. Time: 08:13 \\
Sample (adjusted): 19732018 \\
Included observations 46 after adjustments \\
Standard errors in () \& t-statistics in []
\end{tabular}} \\
\hline Cointegrating Eq: & CointEq1 & & & & & & \\
\hline LINFMOR $\{-1\}$ & 1.000000 & & & & & & \\
\hline LKOFIND(-1) & $\begin{array}{r}1.470863 \\
(0.33085) \\
{[4.44509]}\end{array}$ & & & & & & \\
\hline LREALGDP(-1) & $\begin{array}{r}1.970740 \\
(0.14562) \\
{[13.5335]}\end{array}$ & & & & & & \\
\hline LHELINFR(-1) & $\begin{array}{r}-0.114383 \\
(0.09080) \\
{[-1.25979]}\end{array}$ & & & & & & \\
\hline $\operatorname{LODA}(-1)$ & $\begin{array}{r}-0.176585 \\
(0.03533) \\
{[-4.99747]}\end{array}$ & & & & & & \\
\hline LPOPR(-1) & $\begin{array}{r}-8.815459 \\
(1.11570) \\
{[-7.90126]}\end{array}$ & & & & & & \\
\hline LSANITA(-1) & $\begin{array}{r}-0.830767 \\
(1.05908) \\
{[-0.78442]}\end{array}$ & & & & & & \\
\hline LGOVHEXP(-1) & $\begin{array}{r}-0.053637 \\
\{0.12041\} \\
{[-0.44543]}\end{array}$ & & & & & & \\
\hline C & -22.33556 & & & & & & \\
\hline Error Correction: & D(LINFMOR) & D(LKOFIND) & D(LREALGDP & D(LHELNFR) & D(LODA) & $D(L P O P R)$ & D(LSANITA) \\
\hline CointEq1 & $\begin{array}{r}0.000555 \\
(0.00121) \\
\{-0.45552\}\end{array}$ & $\begin{array}{c}0.118803 \\
(0.07587) \\
{[1.56598]}\end{array}$ & $\begin{array}{r}-0.526935 \\
(0.10312) \\
{[-5.10995]}\end{array}$ & $\begin{array}{r}-0.016882 \\
(0.13367) \\
{[-0.12629]}\end{array}$ & $\begin{array}{r}0.780405 \\
(0.47443) \\
{[1.64493]}\end{array}$ & $\begin{array}{r}0.005293 \\
(0.00245) \\
{[2.15757]}\end{array}$ & $\begin{array}{r}-0.000757 \\
(0.00075) \\
{[-1.01288]}\end{array}$ \\
\hline D(LINFMOR $(-1))$ & $\begin{array}{r}1.700302 \\
(0.14974) \\
{[11.3550]}\end{array}$ & $\begin{array}{r}-4.240422 \\
(9.35096) \\
{[-0.45347]}\end{array}$ & $\begin{array}{l}13.40935 \\
(12.7102) \\
(1.05500)\end{array}$ & $\begin{array}{l}27.28772 \\
(16.4760) \\
{[1.65621]}\end{array}$ & $\begin{array}{r}-13.36451 \\
(58.4769) \\
{[-0.22854]}\end{array}$ & $\begin{array}{r}-0.960140 \\
(0.30239) \\
{[-3.17516]}\end{array}$ & $\begin{array}{l}0.122342 \\
(0.09211) \\
{[1.32820]}\end{array}$ \\
\hline D(UNFMOR(-2)) & $\begin{array}{r}-0.716569 \\
\langle 0.14503) \\
{[-4.94069]}\end{array}$ & $\begin{array}{l}4.203716 \\
(9.05710) \\
{[0.46413]}\end{array}$ & $\begin{array}{r}-5.718563 \\
(12.3108) \\
{[-0.46452]}\end{array}$ & $\begin{array}{r}-28.03213 \\
(15.9582) \\
{[-1.75659]}\end{array}$ & $\begin{array}{l}23.32065 \\
(56.6393) \\
{[0.41174]}\end{array}$ & $\begin{array}{r}0.578374 \\
(0.29289) \\
{[1.97473]}\end{array}$ & $\begin{array}{r}-0.074186^{\circ} \\
(0.08922) \\
{[-0.83153]}\end{array}$ \\
\hline D(LKOFIND(-1)) & $\begin{array}{r}-0.001851 \\
(0.00424) \\
{[-0.43838]}\end{array}$ & $\begin{array}{c}-0.793824 \\
(0.26487) \\
{[-2.99704]}\end{array}$ & $\begin{array}{r}-1.086125 \\
(0.36002) \\
{[-3.01693]}\end{array}$ & $\begin{array}{r}-0.629873 \\
(0.46669) \\
{[-1.34986]}\end{array}$ & $\begin{array}{r}-3.436945 \\
(1.65638) \\
{[-2.07497]}\end{array}$ & $\begin{array}{c}0.001512 \\
(0.00857) \\
{[0.17654]}\end{array}$ & $\begin{array}{l}0.000621 \\
(0.00261) \\
{[0.23602]}\end{array}$ \\
\hline $\mathrm{D}(\operatorname{LKOFIND}(-2))$ & $\begin{array}{l}0.002628 \\
\{0.00535) \\
0.49125]\end{array}$ & $\begin{array}{r}-0.459982 \\
(0.33405) \\
{[-1.37694]}\end{array}$ & $\begin{array}{r}-0.029941 \\
(0.45405) \\
{[-0.06594]}\end{array}$ & $\begin{array}{r}-0.364813 \\
(0.58858) \\
{[-0.61982]}\end{array}$ & $\begin{array}{r}0.249102 \\
(2.08899) \\
{[0.11925]}\end{array}$ & $\begin{array}{c}0.004859 \\
(0.01080) \\
{[0.44882]}\end{array}$ & $\begin{array}{c}-0.001090 \\
(0.00329) \\
{[-0.33127]}\end{array}$ \\
\hline D(LREALGDP(-1)) & 0.001037 & -0.127923 & 0.359839 & -0.139053 & 0.068626 & -0.004700 & 0.000670 \\
\hline
\end{tabular}




\begin{tabular}{|c|c|c|c|c|c|c|c|}
\hline & $\begin{array}{l}(0.00172) \\
{[0.60227]}\end{array}$ & $\begin{array}{r}(0.10750) \\
{[-1.18993]}\end{array}$ & $\begin{array}{l}(0.14613) \\
{[2.46253]}\end{array}$ & $\begin{array}{l}(0.18942) \\
{[-0.73410]}\end{array}$ & $\begin{array}{l}(0.67229) \\
{[0.09910]}\end{array}$ & $\begin{array}{r}(0.00348) \\
{[-1.35202]}\end{array}$ & $\begin{array}{l}(0.00106) \\
{[0.63254]}\end{array}$ \\
\hline D(LREALGDP $(-2))$ & $\begin{array}{c}0.000750 \\
(0.00112) \\
{[0.66922]}\end{array}$ & $\begin{array}{c}0.016032 \\
(0.06996) \\
{[0.22917]}\end{array}$ & $\begin{array}{c}0.119103 \\
(0.09509) \\
{[1.25255]}\end{array}$ & $\begin{array}{l}0.051119 \\
(0.12326) \\
{[0.49585]}\end{array}$ & $\begin{array}{c}0.048142 \\
(0.43748) \\
{[0.11004]}\end{array}$ & $\begin{array}{r}-0.005145 \\
(0.00226) \\
{[-2.27436]}\end{array}$ & $\begin{array}{c}0.000757 \\
(0.00069) \\
{[1.09860]}\end{array}$ \\
\hline DYLHELINFR $(-1)$ ) & $\begin{array}{r}-0.000515 \\
(0.001777) \\
{[-0.29150]}\end{array}$ & $\begin{array}{c}-0.040991 \\
(0.11027) \\
{[-0.37174]}\end{array}$ & $\begin{array}{r}-0.216879 \\
(0.14988) \\
{[-1.44700]}\end{array}$ & $\begin{array}{c}0.508467 \\
(0.19429) \\
{[2.61707]}\end{array}$ & $\begin{array}{r}-0.421582 \\
(0.68957) \\
{[-0.61137]}\end{array}$ & $\begin{array}{r}-0.000738 \\
(0.00357) \\
{[-0.20689]}\end{array}$ & $\begin{array}{r}-0.001992 \\
(0.00109) \\
(-1.83354)\end{array}$ \\
\hline DQLHELINFR(-2)) & $\begin{array}{c}0.000402 \\
(0.00161) \\
{[0.24969]}\end{array}$ & $\begin{array}{r}0.038778 \\
(0.10053) \\
{[0.38575]}\end{array}$ & $\begin{array}{r}-0.077881 \\
(0.13664) \\
{[-0.56997]}\end{array}$ & $\begin{array}{l}0.274957 \\
(0.17712) \\
{[-1.55235]}\end{array}$ & $\begin{array}{l}-0.177721 \\
(0.62865) \\
{[-0.28270]}\end{array}$ & $\begin{array}{r}-0.000402 \\
(0.00325) \\
{[-0.12372]}\end{array}$ & $\begin{array}{c}0.000381 \\
(0.00099) \\
{[0.38448]}\end{array}$ \\
\hline $\mathrm{D}(\operatorname{LODA}(-1))$ & $\begin{array}{c}0.000316 \\
(0.00041) \\
{[0.76888]}\end{array}$ & $\begin{array}{l}0.032765 \\
(0.02563) \\
{[1.27859]}\end{array}$ & $\begin{array}{r}0.013815 \\
(0.03483) \\
{[0.39663]}\end{array}$ & $\begin{array}{r}-0.053919 \\
(0.04515) \\
{[-1.19419]}\end{array}$ & $\begin{array}{c}0.131709 \\
(0.16025) \\
{[0.82188]}\end{array}$ & $\begin{array}{r}-1.03 E-05 \\
(0.00083) \\
{[-0.01240]}\end{array}$ & $\begin{array}{r}6.13 E-05 \\
(0.00025) \\
{[0.24269]}\end{array}$ \\
\hline$D(\operatorname{LODA}(-2))$ & $\begin{array}{c}0.000218 \\
(0.00042) \\
{[0.52037]}\end{array}$ & $\begin{array}{c}0.008959 \\
(0.02616) \\
{[0.34251]}\end{array}$ & $\begin{array}{r}-0.011608 \\
(0.03556) \\
(-0.32648)\end{array}$ & $\begin{array}{l}0.031004 \\
(0.04609) \\
{[0.67269]}\end{array}$ & $\begin{array}{r}0.417524 \\
(0.16358) \\
{[-2.55238]}\end{array}$ & $\begin{array}{c}0.000560 \\
\{0.00085) \\
{[0.66232]}\end{array}$ & $\begin{array}{r}-0.000168 \\
(0.00026) \\
{[-0.65198]}\end{array}$ \\
\hline D(LPOPR(-1)) & $\begin{array}{r}-0.008451 \\
(0.05237) \\
{[-0.16138)}\end{array}$ & $\begin{array}{r}3.502595 \\
(3.27015) \\
{[1.07108)}\end{array}$ & $\begin{array}{r}22.66899 \\
(4.44493) \\
{[5.09696]}\end{array}$ & $\begin{array}{l}3.722213 \\
(5.76186) \\
{[0.64601]}\end{array}$ & $\begin{array}{r}-15.64728 \\
(20.4501) \\
{[-0.76514]}\end{array}$ & $\begin{array}{c}1.361650 \\
(0.10575) \\
{[12.8761]}\end{array}$ & $\begin{array}{l}0.028595 \\
(0.03221) \\
{[0.88769]}\end{array}$ \\
\hline $\mathrm{D}(\operatorname{LPOPR}(-2))$ & $\begin{array}{c}5.81 E-05 \\
(0.05209) \\
{[0.00112]}\end{array}$ & $\begin{array}{r}-0.802332 \\
(3.25302) \\
{[-0.24664]}\end{array}$ & $\begin{array}{c}-26.47092 \\
(4.42165) \\
{[-5.98666]}\end{array}$ & $\begin{array}{r}-4.771959 \\
(5.73168) \\
{[-0.83256]}\end{array}$ & $\begin{array}{c}28.35399 \\
(20.3430) \\
{[1.39380]}\end{array}$ & $\begin{array}{c}0.781416 \\
(0.10520) \\
{[-7.42820]}\end{array}$ & $\begin{array}{r}-0.024615 \\
(0.03204) \\
{[-0.76818]}\end{array}$ \\
\hline $\mathrm{D}(\operatorname{LSANITA}(-1))$ & $\begin{array}{r}-0.283767 \\
(0.30880) \\
{[-0.91894]}\end{array}$ & $\begin{array}{r}-0.590343 \\
(19.2838) \\
{[-0.03051]}\end{array}$ & $\begin{array}{r}-44.27767 \\
(26.2115) \\
{[-1.68925)}\end{array}$ & $\begin{array}{r}-17.13246 \\
(33.9774) \\
\{-0.50423\}\end{array}$ & $\begin{array}{r}-27.80197 \\
(120.593) \\
{[-0.23054]}\end{array}$ & $\begin{array}{c}0.712826 \\
(0.62360) \\
{[1.14308]}\end{array}$ & $\begin{array}{r}0.253302 \\
(0.18995) \\
{[1.33349]}\end{array}$ \\
\hline $\mathrm{D}($ LSANITA $(-2))$ & $\begin{array}{l}0.205530 \\
(0.28646) \\
{[0.77133]}\end{array}$ & $\begin{array}{l}21.65104 \\
\{16.6400) \\
{[1.30115]}\end{array}$ & $\begin{array}{r}-30.20444 \\
(22.6178) \\
(-1.33543)\end{array}$ & $\begin{array}{l}17.13545 \\
(29.3189) \\
{[0.58445]}\end{array}$ & $\begin{array}{l}142.6272 \\
(104.059) \\
{[1.37064]}\end{array}$ & $\begin{array}{l}0.414832 \\
(0.53810) \\
{[0.77092]}\end{array}$ & $\begin{array}{c}0.506937 \\
(0.16391) \\
{[3.09276]}\end{array}$ \\
\hline $\mathrm{D}($ LGOVHEXP(-1)) & $\begin{array}{r}-0.001505 \\
(0.00156) \\
{[-0.06775]}\end{array}$ & $\begin{array}{r}-0.041241 \\
(0.09711) \\
{[-0.424681}\end{array}$ & $\begin{array}{c}0.003550 \\
(0.13200) \\
{[0.02690]}\end{array}$ & $\begin{array}{l}0.100229 \\
(0.17111) \\
{[0.58577]}\end{array}$ & $\begin{array}{r}-1.167359 \\
(0.60730) \\
{[-1.92223]}\end{array}$ & $\begin{array}{l}0.006982 \\
(0.00314) \\
{[2.22341]}\end{array}$ & $\begin{array}{c}-0.000711 \\
(0.00096) \\
{[-0.74367]}\end{array}$ \\
\hline $\mathrm{D}($ LGOVHEXP(-2)) & $\begin{array}{c}0.000400 \\
(0.00137) \\
{[0.29212]}\end{array}$ & $\begin{array}{c}0.036983 \\
(0.08552) \\
{[0.43246]}\end{array}$ & $\begin{array}{r}-0.028374 \\
(0.11624) \\
(-0.24410)\end{array}$ & $\begin{array}{c}0.048565 \\
(0.15068) \\
{[0.32231]}\end{array}$ & $\begin{array}{r}-0.913184 \\
(0.53479) \\
{[-1.70754]}\end{array}$ & $\begin{array}{c}0.004928 \\
(0.00277) \\
{[1.78214]}\end{array}$ & $\begin{array}{c}0.000154 \\
(0.00084) \\
{[0.18281]}\end{array}$ \\
\hline c & $\begin{array}{l}0.001831 \\
(0.00698) \\
{[0.26251]}\end{array}$ & $\begin{array}{r}-0.637218 \\
(0.43563) \\
{[-1.46274]}\end{array}$ & $\begin{array}{l}2.653263 \\
(0.59213) \\
{[4.48087]}\end{array}$ & $\begin{array}{r}-0.036922 \\
(0.76757) \\
{[-0.04810]}\end{array}$ & $\begin{array}{r}-3.204883 \\
(2.72426) \\
{[-1.17642]}\end{array}$ & $\begin{array}{r}-0.044378 \\
(0.01409) \\
{[-3.15020]}\end{array}$ & $\begin{array}{r}0.006495 \\
(0.00429) \\
{[1.51358]}\end{array}$ \\
\hline $\begin{array}{l}\text { R-squared } \\
\text { Adj, R-squared } \\
\text { Sum sq. resids } \\
\text { S. E. equation } \\
\text { F-statistic } \\
\text { Log Bkelihood } \\
\text { Akake AIC } \\
\text { Schwarz SC } \\
\text { Mean dependent } \\
\text { S.D. dependent }\end{array}$ & $\begin{array}{l}0.993024 \\
0.988789 \\
6.19 \mathrm{E}-05 \\
0.001487 \\
234.4726 \\
245.6451 \\
-9.897614 \\
-9.182069 \\
-0.020233 \\
0.014046\end{array}$ & $\begin{array}{l}0.534099 \\
0.251230 \\
0.241524 \\
0.092875 \\
1.888152 \\
55.46571 \\
-1.628944 \\
-0.913388 \\
0.017759 \\
0.107331\end{array}$ & $\begin{array}{r}0.901352 \\
0.841458 \\
0.446227 \\
0.126241 \\
15.04919 \\
41.34693 \\
-1.015084 \\
-0.299529 \\
0.120317 \\
0.317049\end{array}$ & $\begin{array}{l}0.609231 \\
0.371978 \\
0.749811 \\
0.163643 \\
2.567856 \\
29.41007 \\
-0.496090 \\
0.219465 \\
0.010650 \\
0.206495\end{array}$ & $\begin{array}{c}0.3998991 \\
0035551 \\
9.445313 \\
0.580803 \\
1.097575 \\
-28.85935 \\
2.037353 \\
2.752918 \\
-0.008124 \\
0.591411\end{array}$ & $\begin{array}{l}0.988238 \\
0.981097 \\
0.000253 \\
0.003003 \\
138.3839 \\
213.3153 \\
-8.491971 \\
-7.776415 \\
0.001595 \\
0.021845\end{array}$ & $\begin{array}{l}0.997428 \\
0.995 B 65 \\
2.34 \mathrm{E}-05 \\
0.000915 \\
638.7269 \\
267.9987 \\
-10.86942 \\
10.15385 \\
0.030200 \\
0.014230\end{array}$ \\
\hline $\begin{array}{l}\text { Determinant resid cov } \\
\text { Determinant resid } \infty \mathrm{v}\end{array}$ & dof adj & $\begin{array}{l}6.59 \mathrm{E}-26 \\
1.24 \mathrm{E}-27\end{array}$ & & & & & \\
\hline
\end{tabular}

This publication is licensed under Creative Commons Attribution CC BY. 
Variance Decomposition using Cholesky (d f adjusted) Factors

\begin{tabular}{|c|c|c|c|c|c|c|c|c|}
\hline \multicolumn{9}{|c|}{ Variance Decomposition of LNFMOR: } \\
\hline & & LINFMOR & LKOFIND & LREALGDP & LHELINFR & LODA & LPOPR & LSANITA \\
\hline 1 & 0.001175 & 100.0000 & 0000000 & 0.000000 & 0.000000 & 0.000000 & 0.000000 & 0.000000 \\
\hline 2 & 0,002588 & 97.35759 & 0.074042 & 0.386661 & 0.089147 & 0.265574 & 0.006414 & 0.072293 \\
\hline 3 & 0.004241 & 93.47529 & 0.125190 & 1.065283 & 0.102084 & 0.756575 & 0.004033 & 0.054619 \\
\hline 4 & 0.006072 & 88.44631 & 0.633390 & 1.904380 & 0.088478 & 1.411748 & 0.022742 & 0.032215 \\
\hline 5 & 0.008097 & 82.52624 & 1.476705 & 2.820016 & 0.116742 & 2.352035 & 0.138200 & 0.018128 \\
\hline 6 & 0.010362 & 75.94953 & 2354951 & 3.777889 & 0.180014 & 3.705508 & 0.430588 & 0.019032 \\
\hline 7 & 0.012879 & 69.00607 & 3.176065 & 4.846686 & 0.219871 & 5.391522 & 0.948513 & 0.054162 \\
\hline 8 & 0.015664 & 61.90279 & 3.900790 & 6.137255 & 0.286617 & 7241540 & 1.675172 & 0.143785 \\
\hline 9 & 0.018724 & 54.85297 & 4.503887 & 7.637590 & 0.344006 & 9.113417 & 2.533885 & 0.295813 \\
\hline 10 & 0.022043 & 48.14919 & 4.962834 & 9.193972 & 0.378270 & 10.90549 & 3.420313 & 0.501842 \\
\hline \multicolumn{9}{|c|}{ Variance Decomposition of LKOFIND: } \\
\hline Period & S.E. & LNFMOR & LKOFIND & LREALGDP & LHELINFR & LODA & LPOPR & LSANITA \\
\hline 1 & 0.074729 & 6. 120752 & 91.87925 & 0.000000 & 0,000000 & 0,000000 & 0.000000 & 0.000090 \\
\hline 2 & 0.079826 & 7.138533 & 81.59342 & 2.936287 & 2.128390 & 1.590130 & 3.456282 & 0.314821 \\
\hline 3 & 0.088933 & 6.055845 & 65.73919 & 15.54950 & 2.259110 & 4.646952 & 4.080904 & 0.319381 \\
\hline 4 & 0.095107 & 5.301168 & 58.05695 & 22.70750 & 2.326340 & 4.219443 & 4.1288387 & 0.339391 \\
\hline 5 & 0.098284 & 5.201251 & 55.12135 & 21.53608 & $2.99501 \mathrm{~B}$ & 3.982146 & 3. 944555 & 0.324015 \\
\hline 6 & 0.100763 & 5.327338 & 52.57305 & 22.14710 & 3.496122 & 3.809923 & 3.822532 & 0.360881 \\
\hline 7 & 0.103432 & 5.323215 & 50.48343 & 24.15324 & 3.508804 & 3.850522 & 4.056437 & 0.554897 \\
\hline 8 & 0.106539 & 5.023187 & 49.36338 & 25.10950 & 3.327291 & 3.799264 & 4.585035 & 0.903350 \\
\hline 9 & 0.109358 & 4.989987 & 48.03016 & 25.60317 & 3.540255 & 3.610931 & 5.083556 & 1.166444 \\
\hline 10 & 0.111680 & 5.559192 & 46.38640 & 2590099 & 4.075498 & 3.496744 & 5.245893 & 1.233578 \\
\hline \multicolumn{9}{|c|}{ Veriance Decomposition of LREALGDP: } \\
\hline Period & $S F$ & LINFMOR & LKOFIND & LREALGDP & LHELINFR & LODA & LPOPR & LSANITA \\
\hline 1 & 0.150559 & 5.563577 & 4.749416 & 8968701 & 0.000000 & 0.000000 & 0.000000 & 0.000000 \\
\hline 2 & 0.234371 & 5.069818 & 33.97000 & 58.94923 & 0.068614 & 0.015525 & 0.210197 & 0.685689 \\
\hline 3 & 0.248944 & 4.500789 & 30.12185 & 52.51623 & 0.678057 & 1.461004 & 0.425869 & 0.609776 \\
\hline 4 & 0.274401 & 3.781741 & 25.66050 & 50.80275 & 0.560085 & 4.020838 & 0.350707 & 0.509075 \\
\hline 5 & 0.284210 & 3570823 & 24.43872 & 53.16408 & 0.580526 & 4.026463 & 0.362738 & 0.477813 \\
\hline 6 & 0.289937 & 3.433642 & 26.26244 & 51.08487 & 0.644346 & 3.869300 & 0.412256 & 0.472162 \\
\hline 7 & 0.297196 & 3.308793 & 26.64910 & 50.69205 & 1.060017 & 3.913378 & 0.524298 & 0.449493 \\
\hline 8 & 0.302363 & 3.273644 & 25.75028 & 50.46226 & 1.424159 & 4.686176 & 0.742487 & 0.503798 \\
\hline 9 & 0.306453 & 3.188620 & 25.40082 & 49.40097 & 1.447605 & 5.324435 & 1.081739 & 0.706835 \\
\hline 10 & 0.308718 & 3248190 & 25.14783 & 48.82999 & 1.449781 & 5.438697 & 1.429162 & 0.892115 \\
\hline \multicolumn{9}{|c|}{ Variance Decomposition of LHELINFR. } \\
\hline & S.E. & UNFMOR & LKOFIND & LREALGDP & LHELINFR & LODA & LPOPR & LSANITA \\
\hline 1 & 0.127413 & 14.50123 & 3.965635 & 2.515668 & 79.01747 & 0.000000 & 0.000000 & 0.000000 \\
\hline 2 & 0.208909 & 11.558888 & 22.89109 & 2.938539 & 55.76318 & 5.325852 & 0.487140 & 1.026544 \\
\hline 3 & 0.263805 & 12.69053 & 25.53446 & 1.972957 & 43.65895 & 13.00519 & 0.483135 & 1.4388686 \\
\hline 4 & 0.294671 & 13.20465 & 24.68865 & 1.581896 & 36.50831 & 18.56332 & 0.387988 & 2.077884 \\
\hline 5 & 0.309755 & 13.41552 & 23,89188 & 1.470110 & 33.12600 & 20.79880 & 0.394081 & 2.523212 \\
\hline 6 & 0.316415 & 13.64336 & 23.48331 & 1.487930 & 31.76328 & 21.36764 & 0.414517 & 2.669143 \\
\hline 7 & 0.320189 & 13.96783 & 23.09964 & 1.680825 & 31.05885 & 21.46172 & 0.413055 & 2.697536 \\
\hline 8 & 0.324451 & 14.20838 & 22.51674 & 2321360 & 3026114 & 21.35325 & 0.682486 & 2.664027 \\
\hline 9 & 0.331833 & 14.05403 & 21.52611 & 3.909323 & 28.92983 & 20.96887 & 1.583838 & 2.623029 \\
\hline 10 & 0.343739 & 13.32316 & 20.06078 & 6.625628 & 26.96170 & 20.30360 & 3.049366 & 2.627296 \\
\hline \multicolumn{9}{|c|}{ Variance Decomposition of LODA. } \\
\hline Period & S.E. & UNFMOR & LKOFIND & LREALGDP & LHELINFR & LOOA & IPOPR & ISANITA \\
\hline & 0.522000 & 11.54083 & 1,565354 & 1. 366583 & 0.061780 & $85.4654 B$ & 0.000000 & 0.000000 \\
\hline 2 & 0.649001 & 9.956726 & 1.127804 & 1.997370 & 4.410287 & 78.65814 & 0.515489 & 3. 203492 \\
\hline 3 & $0.70906 \mathrm{~d}$ & B.561637 & 0.946737 & 1.831103 & 10.01474 & 67.64658 & 1.117675 & 7.839961 \\
\hline 4 & 0.732813 & 8.371693 & 0.901900 & 2081815 & 11.99810 & 63.61028 & 1.077517 & 9.154308 \\
\hline
\end{tabular}


Variance Decomposition using Cholesky (d.f. adjusted) Factors

\begin{tabular}{|c|c|c|c|c|c|c|c|c|}
\hline $\begin{array}{c}5 \\
6 \\
7 \\
8 \\
9 \\
10\end{array}$ & $\begin{array}{l}0.740792 \\
0.756243 \\
0.776935 \\
0.795002 \\
0.805090 \\
0.811140\end{array}$ & $\begin{array}{l}8.369430 \\
8.045997 \\
7.759323 \\
7.854353 \\
8.190852 \\
8.575602\end{array}$ & $\begin{array}{l}1.049090 \\
2.571768 \\
4.200684 \\
5.031722 \\
5.322348 \\
5.391902\end{array}$ & $\begin{array}{l}2.829892 \\
3.965608 \\
5.045928 \\
5.838373 \\
6.112598 \\
6.059734\end{array}$ & $\begin{array}{l}11.76460 \\
12.02234 \\
12.97952 \\
13.68837 \\
13.97011 \\
14.01654\end{array}$ & $\begin{array}{l}62.49481 \\
60.00862 \\
56.97556 \\
54.91500 \\
53.89136 \\
53.45525\end{array}$ & $\begin{array}{l}1.115094 \\
1.216321 \\
1.306888 \\
1.364212 \\
1.396082 \\
1.402381\end{array}$ & $\begin{array}{l}9.589921 \\
9.369235 \\
8.918257 \\
8.517572 \\
8.309677 \\
8.249079\end{array}$ \\
\hline \multicolumn{9}{|c|}{ Variance Decomposition of LPOPR: } \\
\hline Period & S.E. & LINFMOR & LKOFIND & LREALGDP & LHELINFR & LODA & LPOPR & LSANITA \\
\hline $\begin{array}{c}1 \\
2 \\
3 \\
4 \\
5 \\
6 \\
7 \\
8 \\
9 \\
10\end{array}$ & $\begin{array}{l}0.004121 \\
0.009465 \\
0.015336 \\
0.020272 \\
0.023611 \\
0.025476 \\
0.026575 \\
0.027683 \\
0.029136 \\
0.030741\end{array}$ & $\begin{array}{l}2.211855 \\
0.829641 \\
0.351669 \\
1.243678 \\
3.495932 \\
6.923716 \\
10.59825 \\
12.93786 \\
13.18131 \\
12.17714\end{array}$ & $\begin{array}{l}2.527475 \\
3.292234 \\
2.984261 \\
2.342111 \\
1.883997 \\
1.619647 \\
1.721457 \\
2.255016 \\
2.857180 \\
3.098585\end{array}$ & $\begin{array}{l}33.84222 \\
46.78893 \\
52.28149 \\
52.21140 \\
48.50221 \\
43.52955 \\
40.13665 \\
39.76060 \\
41.25223 \\
42.46661\end{array}$ & $\begin{array}{l}0.009083 \\
0.003589 \\
0.031378 \\
0.252752 \\
0.763992 \\
1.539190 \\
2.188479 \\
2.311408 \\
2.089031 \\
2.041662\end{array}$ & $\begin{array}{l}0.743423 \\
2.877972 \\
3.929300 \\
4.358034 \\
4.604692 \\
4.673108 \\
4.482400 \\
4.131629 \\
3.795320 \\
3.562033\end{array}$ & $\begin{array}{l}60.68594 \\
44.49534 \\
34.77981 \\
29.05043 \\
25.17193 \\
22.42849 \\
20.61789 \\
19.68267 \\
19.27399 \\
18.90881\end{array}$ & $\begin{array}{l}0.000000 \\
0.701062 \\
1.658701 \\
2.567102 \\
3.047239 \\
3.136482 \\
2.962464 \\
2.745683 \\
2.629537 \\
2.578549\end{array}$ \\
\hline $\begin{array}{l}\text { Variance } \\
\text { Period }\end{array}$ & \multicolumn{8}{|c|}{ Variance Decomposition of LSANITA: } \\
\hline $\begin{array}{c}1 \\
2 \\
3 \\
4 \\
5 \\
6 \\
7 \\
8 \\
9 \\
10\end{array}$ & $\begin{array}{l}0.000825 \\
0.001366 \\
0.001914 \\
0.002469 \\
0.003018 \\
0.003557 \\
0.004079 \\
0.004582 \\
0.005064 \\
0.005526\end{array}$ & $\begin{array}{l}2.957657 \\
1.162686 \\
1.694860 \\
2.624543 \\
3.072343 \\
3.160297 \\
3.030103 \\
2.820241 \\
2.590809 \\
2.369273\end{array}$ & $\begin{array}{l}1.435049 \\
1.488627 \\
1.297493 \\
1.190553 \\
1.218095 \\
1.292841 \\
1.321899 \\
1.281269 \\
1.161433 \\
1.001272\end{array}$ & $\begin{array}{l}6.675013 \\
9.951321 \\
11.77431 \\
14.36062 \\
17.56018 \\
20.83783 \\
23.49914 \\
25.31993 \\
26.42361 \\
27.02924\end{array}$ & $\begin{array}{l}0.695681 \\
1.736067 \\
2.204521 \\
1.754119 \\
1.202751 \\
0.889612 \\
0.787930 \\
0.781761 \\
0.786531 \\
0.764156\end{array}$ & $\begin{array}{l}12.43696 \\
14.43136 \\
17.95552 \\
20.38003 \\
20.99833 \\
20.57905 \\
19.87302 \\
19.27858 \\
18.93790 \\
18.86393\end{array}$ & $\begin{array}{l}0.000362 \\
0.004695 \\
0.150095 \\
0.503578 \\
0.938661 \\
1.426977 \\
1.963058 \\
2.533422 \\
3.112263 \\
3.656483\end{array}$ & $\begin{array}{l}75.79928 \\
70.96644 \\
64.10433 \\
57.15304 \\
51.47542 \\
46.49767 \\
42.24048 \\
38.65726 \\
35.70818 \\
33.28692\end{array}$ \\
\hline $\begin{array}{l}\text { Variance } \\
\text { Period }\end{array}$ & $\begin{array}{l}\text { composition } \\
\text { S.E. }\end{array}$ & $\begin{array}{l}\text { t LGOVHEX } \\
\text { LINFMOR }\end{array}$ & LKOFIND & LREALGDP & LHELINFR & LODA & LPOPR & LSANITA \\
\hline $\begin{array}{c}1 \\
2 \\
3 \\
4 \\
5 \\
6 \\
7 \\
8 \\
9 \\
10\end{array}$ & $\begin{array}{l}0.163743 \\
0.189560 \\
0.205341 \\
0.228687 \\
0.247334 \\
0.262065 \\
0.272680 \\
0.283256 \\
0.296831 \\
0.311688\end{array}$ & $\begin{array}{l}13.99062 \\
11.16671 \\
10.79705 \\
9.163206 \\
9.108535 \\
9.186611 \\
9.292692 \\
9.129524 \\
8.589154 \\
7.857523\end{array}$ & $\begin{array}{l}2.682433 \\
9.720054 \\
17.23871 \\
26.45869 \\
25.76180 \\
23.94974 \\
22.93331 \\
22.05455 \\
20.41077 \\
18.52880\end{array}$ & $\begin{array}{l}1.268993 \\
11.38905 \\
9.725968 \\
8.608853 \\
7.650399 \\
6.830183 \\
6.354183 \\
7.246248 \\
10.08636 \\
12.89068\end{array}$ & $\begin{array}{l}1.053308 \\
1.651830 \\
1.722166 \\
1.836152 \\
2.941384 \\
3.610537 \\
3.890353 \\
3.836872 \\
3.551733 \\
3.221241\end{array}$ & $\begin{array}{l}3.151035 \\
2.442748 \\
3.049660 \\
6.105673 \\
10.64260 \\
14.44388 \\
16.61986 \\
17.72218 \\
18.19187 \\
18.34791\end{array}$ & $\begin{array}{l}3.991713 \\
4.137895 \\
3.928714 \\
3.279748 \\
2.825040 \\
2.631043 \\
2.828961 \\
3.393600 \\
4.126276 \\
4.854593\end{array}$ & $\begin{array}{l}6.372877 \\
5.827516 \\
5.264039 \\
4.315125 \\
3.882840 \\
4.089324 \\
4.533658 \\
4.935634 \\
5.182786 \\
5.381698\end{array}$ \\
\hline
\end{tabular}

This publication is licensed under Creative Commons Attribution CC BY. 


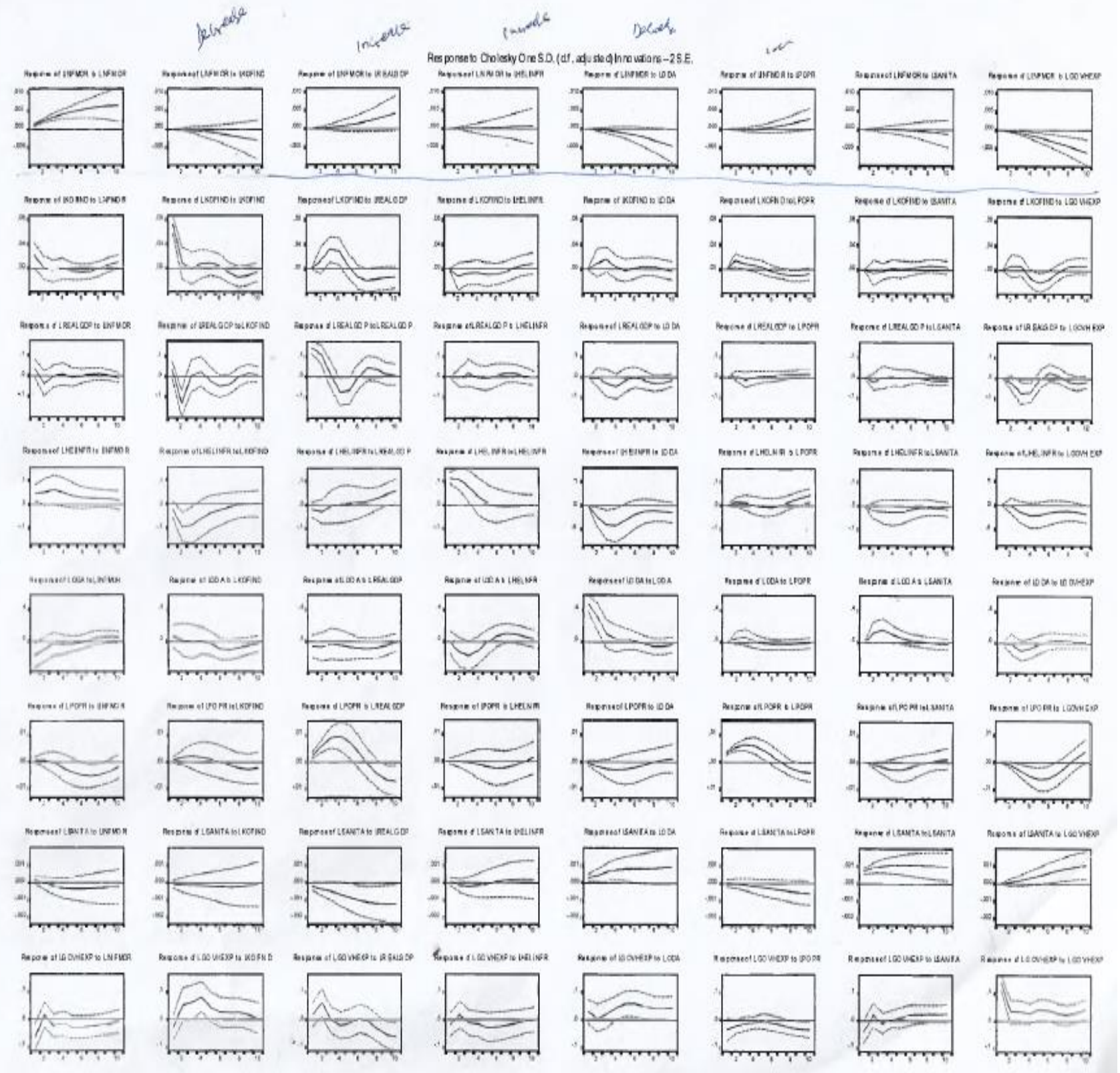

This publication is licensed under Creative Commons Attribution CC BY. 


\section{Inverse Roots of AR Characteristic Polynomial}

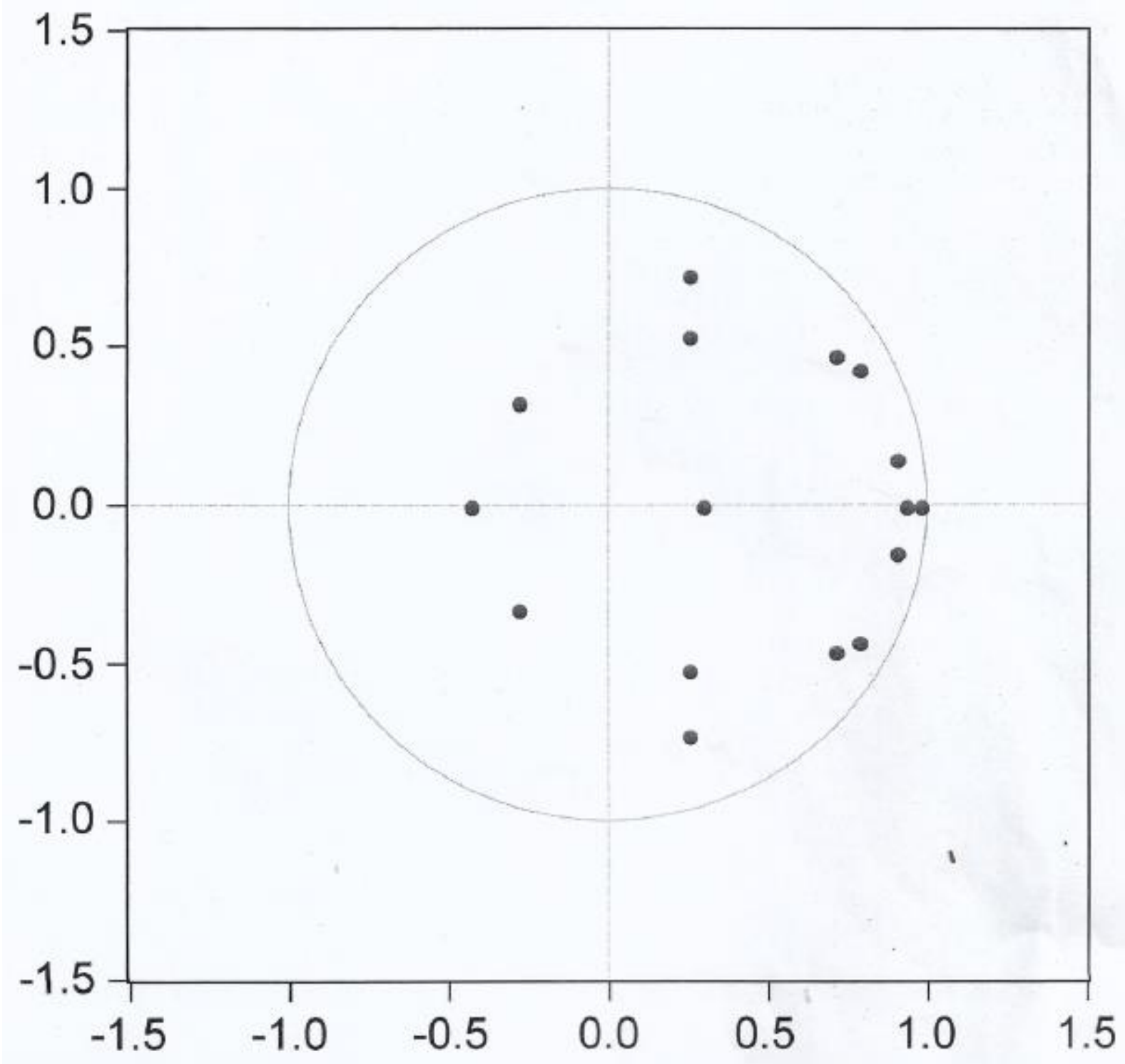

